Historic, Archive Document

Do not assume content reflects current scientific knowledge, policies, or practices. 

...UTICA...

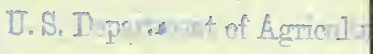

SEED AND SUPPLY STORE

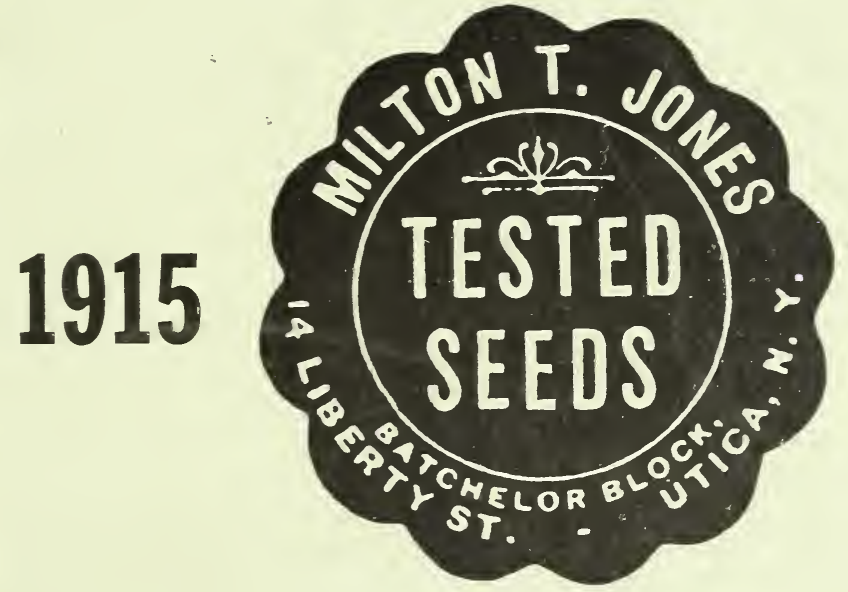

1915

DESCRIPTIVE PRICE LIST

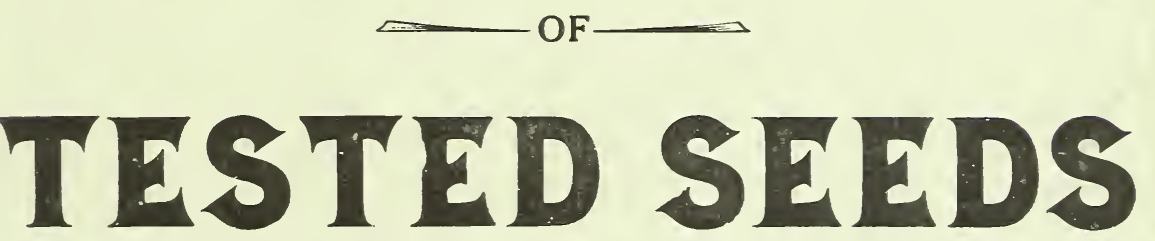

With Reference Table and Foreign Names of Seeds.

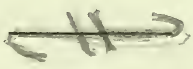

MILTON T. JONES

UTICA, NEW YORK

Also Successor to the Batchelor.Seed Store of this City. 


\section{Foreign Names of Vegetables and Herbs}

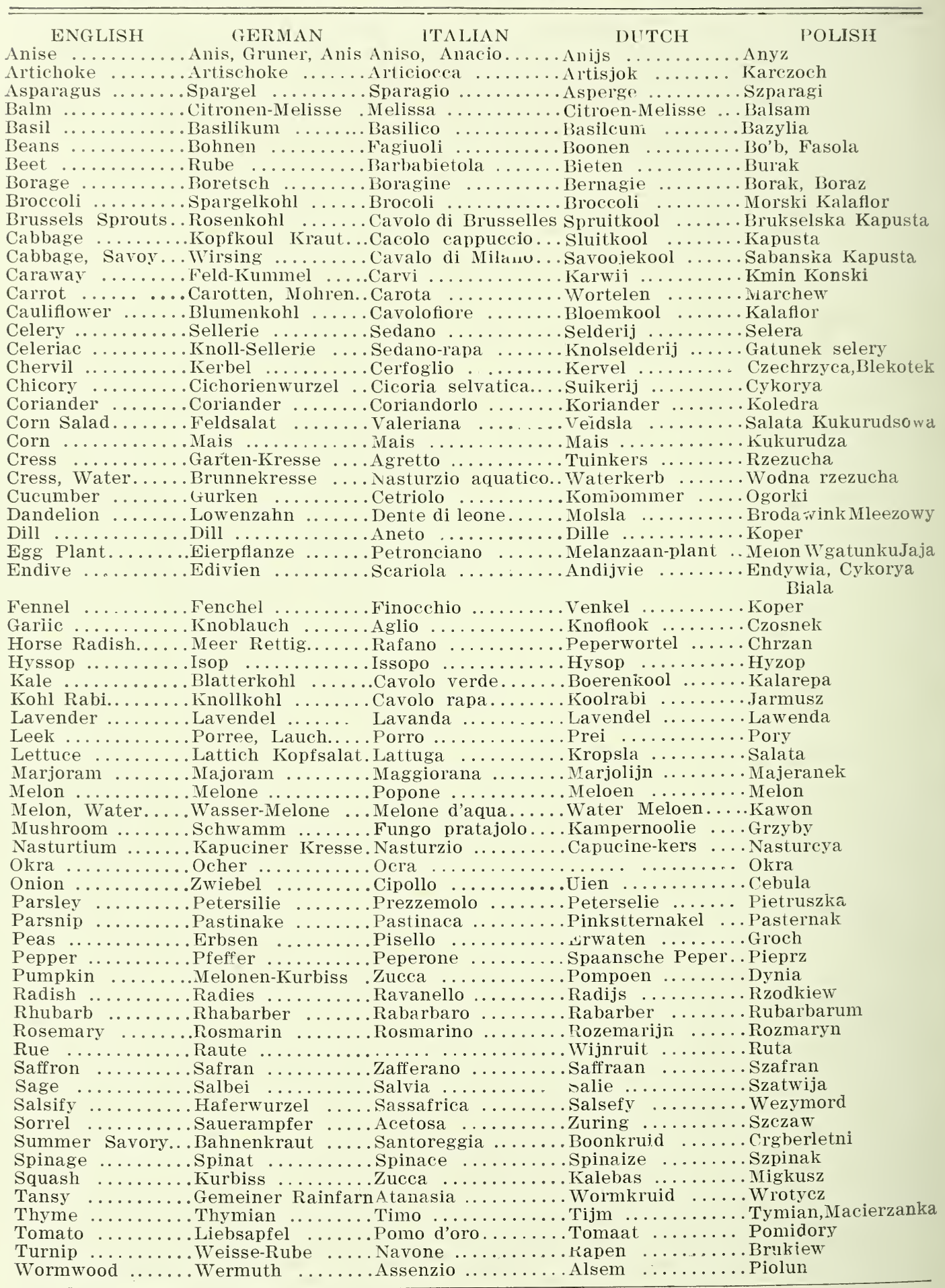




\section{Introdaction}

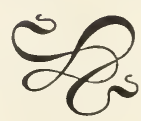

The outlook for 1915 is considerably different from ordinary years. The map of Europe is being changed and bloody battles are being fought on soil that should be producing food for the starving millions of Europe.

America has been depending to a great extent on certain lines of seeds which we have not been able to produce here to advantage. This will have a tendency to run prices up along those lines. On the other hand, there will be a growing demand for all surplus farm products, and the outlook for the American farmer and garden trucker is quite encouraging.

In our own country beans seems to be the lame crop, and the price of these has advanced materially. Some other crops have also proved scarce and on the whole seeds are higher than a year ago.

I expect in the future as in the past to furnish only the most reliable stocks the market affords, true to name and of the highest possible vitality.

Three years ago I purchased the business of the Batchelor Seed Store of this city, and this together with my own business has been run under one management at my present headqquarters, No. 14 Liberty Street, and I take this opportunity of thanking both the patrons of the Batchelor Seed Store and also my own customers for their very generous support during the past year.

Wishing you all a most happy and prosperous new year,

I remain, respectfully yours,

MILTON T. JONES.

Kindly send any orders or correspondence to my address,

\section{MILTON T. JONES,}

BATCHELOR BLOCK, 14 LIBERTY STREET, UTICA，N. Y. 


\section{FLOWER SEEDS}

ABRONIA (Sand Verbena) - Pretty trailing plants, sweet scented... $\$ 0.05 \quad \$ 0.25 \quad \$ 0.75$

ACONITUM (Wolf'sbane)-Hardy perennial, long spikes, flowers

blue and white.................................. $\quad .20 \quad .60$

ACROLINUM (Ererlasting)-Pretty annual, flower white or rosy pink $\quad .05 \quad .10 \quad .25$

ADONIS (Pheasant's Eye)-Hardy annual, fine cut foliage, crimson

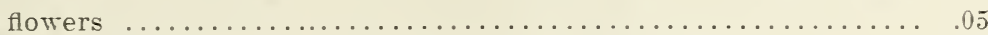

AGERATUM-Fine, sweet flowering plant, grows rapidly.........

AGROSTEMMA (Rose of Heaven)-Hardy perennial, flowers on long,

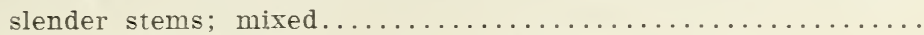

SWEET ALYSSUM-Hardy annual; blossoms early until fall........

AMARANTHUS-Brilliant annual; useful for borders; mixed.......

AMMOBIUM (Winged Everlasting)-Pretty, white annual; sown in

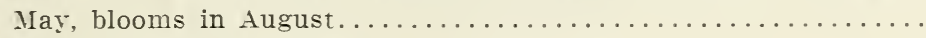

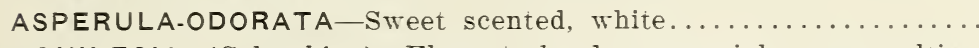

AQUILEGIA (Columbine)-Elegant, hardy perennial; easy cultira-

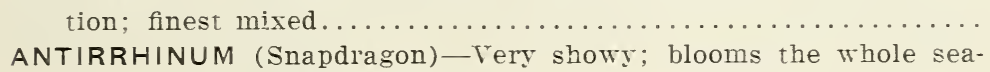

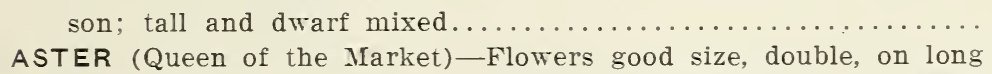

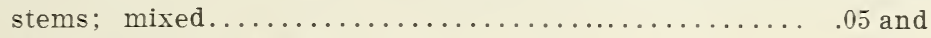

ASTER (Giant Comet) - Tall variety, immense flowers............

ASTER (Giant Comet)-White, rose, dark blue, carmine, lavender...

ASTER-Dwarf chrysanthemum; all colors mixed........ .05 and

ASTER (Semple Branching)-Pink, new Jewel, Apple Blossom, also

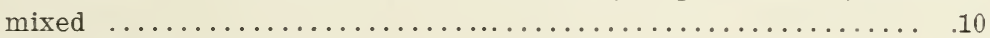

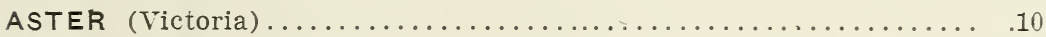

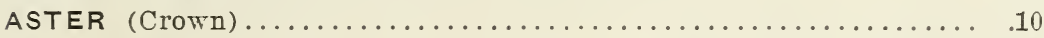

BALLOON VINE-Rapid summer climber; flowers balloon shaped... .05

BALSAM (Lady's Slipper)—Old garden favorite; double mixed..... . . 10

BALSAM (Lady's Slipper) - Royal Double Camelia flowered........ .10

BARTONIA (Aurea)-Showy annual; flowers golden yellow....... . .05

BEGONIA (Tuberous)-Double Begonia; makes fine cut flowers..... . .25

CALENDULA (Pot Marigold)-Hardy annual; grows in nearly any

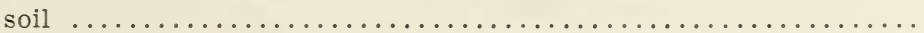

CALLIOPSIS (Golden Ware)-Tery hardy, fine cut flower; grows in

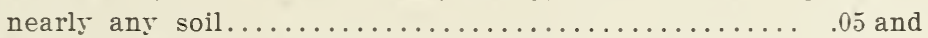

CANARY BIRD FLOWER-Beautiful climber; on Nasturtium order.

CANTERBURY BELLS-Hardy biennial, very ornamental; single and

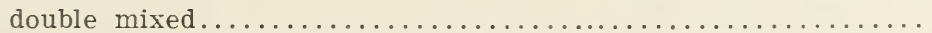

CANDY TUFT-Hardy annual; grows any soil; blooms all

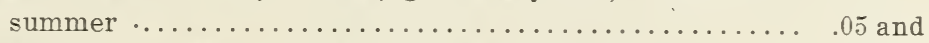

CANDY TUFT-White Rocket, Purple Lilac, mixed....... .05 and

CARNATION (Marguerite)-Pure white, fiery scarlet, double crimson, double mixed..............................$_{10}$

CASTOR BEANS-Fine center plants, stately and strong, all shades..

CANNA (Indian Shot)-Tery ornamental, orange, crimson and rellow

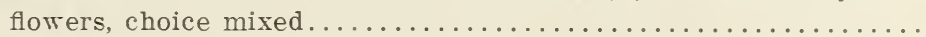

CELOSIA (Cockscomb)-Fine mixture Crimson Pink, Golden Stripe

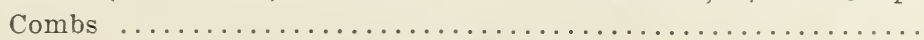

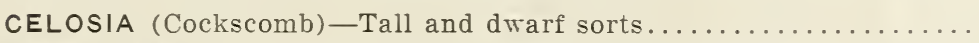

CENTAUREA (Bachelor's Button)-Free blooming, hardy annual;

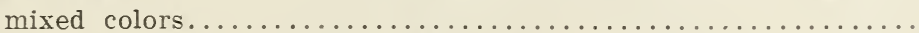

CENTAUREA (Sweet Sultan)-Mixed colors, white, pink, rose and blue 
CHRYSANTHEMUMS-Fine, hardy cut flowers; double white and

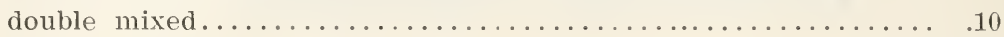

CLARKIA - Single and double sorts................ .05 and .10

COBIA - Hardy perennial climber; bell shaped flowers............ .10

CHINESE PINK-Hardy annual; flowers very brilliant; blooms well .10

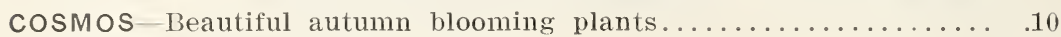

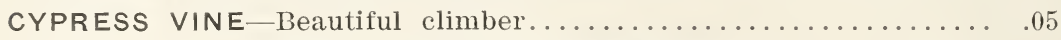

DAHLIA-Can be raised and flowered same season-

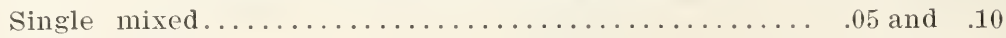

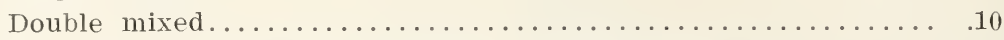

DAISY-Fine for edgings and bol'ders; double mixed and Swan River .10

DIANTHUS (or Pinks)-Beautiful annual, rich in color; blooms

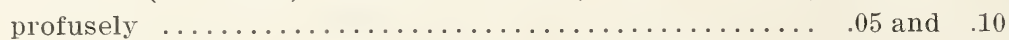

DIANTHUS (or Pinks)-Double Diadem, or Japanese..... .05 and .10

DELPHINIUM (or Larkspur) - Double Tall Rocket (mixed).........

DIGITALIS (Foxglove)-Fine stately plants, adapted for shrubberies

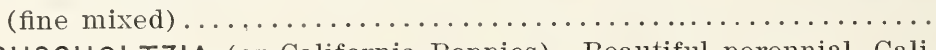

ESCHSCHOLTZIA (or California Poppies)-Beautiful perennial, Cali-

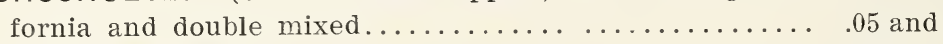

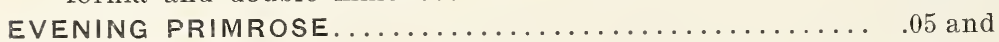

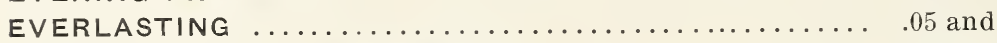

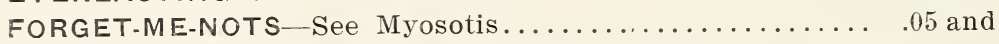

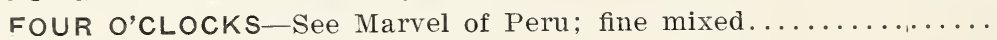

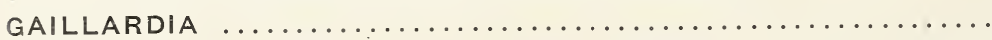

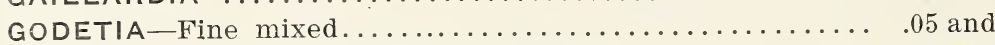

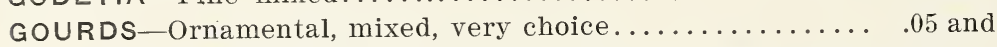
HELIOTROPE-Fragrant, good for pot culture in winter and bedding

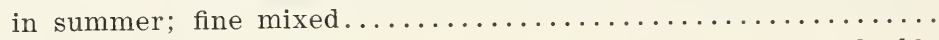

HOLLYHOCK-Old favorite, in pink, rose and red; single and double

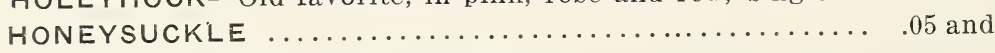

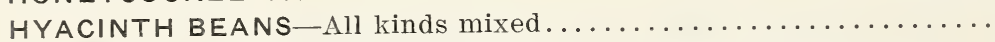
ICE PLANT-Suitable for rock work and hanging baskets......... IPOMCEA (Moonflower)-Quick summer climber for trellises, walls,

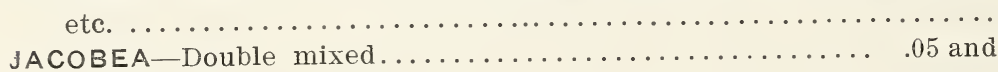

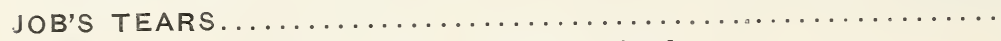

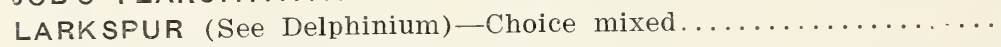

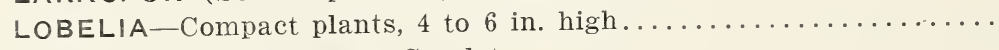

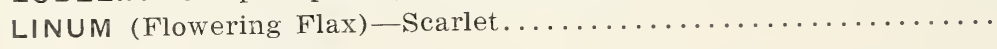

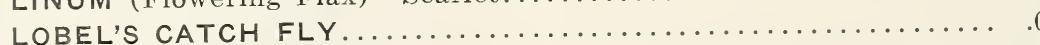

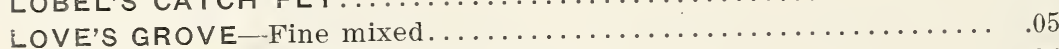

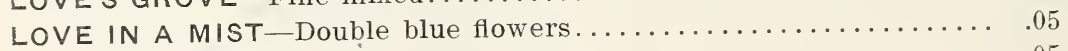

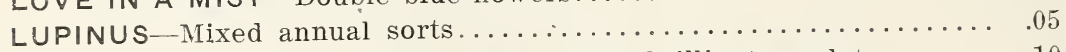

LYCHNIC (or Ragged Robin)-Very hardy; brilliant scarlet....... 10

MARIGOLD-Well known annual, free flowering, easy culture-

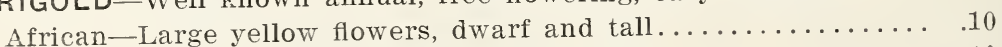

French-Dwarf and tall, beautiful stripe flowers........... 10

MARVEL OF PERU (Four O'Clocks)-Pretty annual, easy growth,

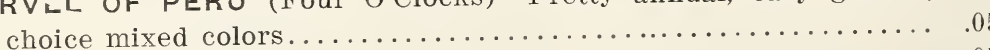

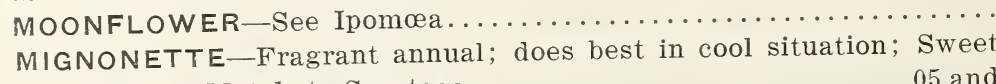

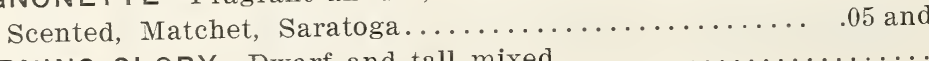

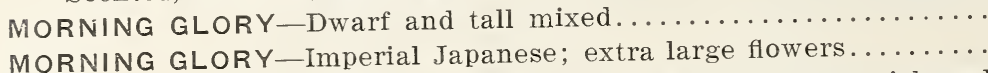
MIMULUS (Monkey Flower)-Good for potting out; flowers rich and

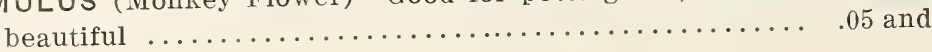


MYOSOTIS (or Forget-Me-Not)

Pkt. 1/4 oz. Oz

Pkt.

Oz. $1 / 4 \mathrm{lb}$. Lb.

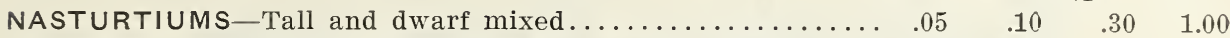

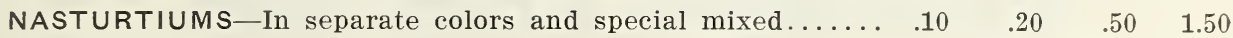

PANSIES_Beaconsfield, Emperor William, King of the Blacks . . . . . $\quad .10 \quad \begin{array}{rrr}10 & .50 & 1.50\end{array}$

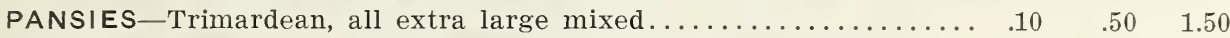

PANSIES_Giant Yellow, Gem White, finest mixed . . . . . . . . . . $10 \quad .50 \quad 1.50$

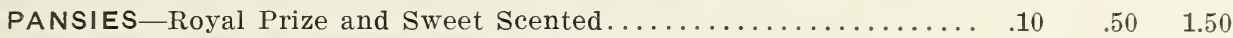

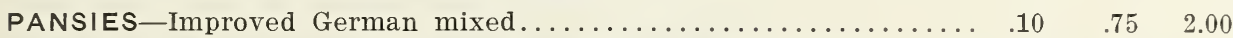

PETUNIA-Flowers early and stays late; Single Hybrid mixed...... . . $10 \quad .25 \quad .75$

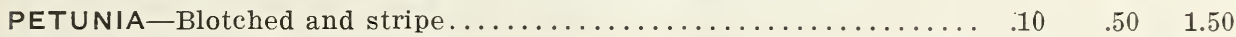

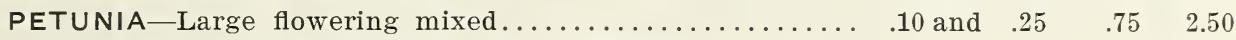

PHLOX-Beautiful annual for beds and massing-

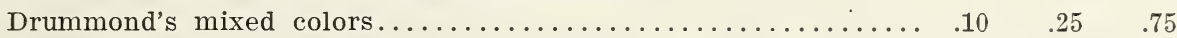

Large flowering, mixed colors . . . . . . . . . . . . . . . . . . . .10 $\quad .50 \quad 1.25$

Large Flowering, white.............................. . . 10 $\quad .50 \quad 1.25$

PINKS (See Dianthus) - Showy, large flowers, fine in clumps or beds.

POPPIES-Cardinal Red, Shirley, Cornell, California, Carnation,

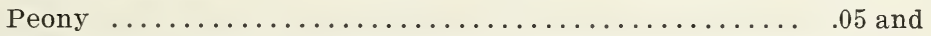

PORTULACA-Brilliant dwarf annuals, desirable for low beds-

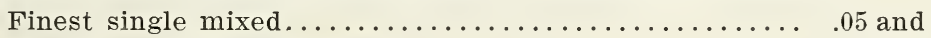

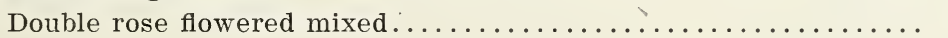

SWEET PEAS-Finest assortment in separate colors (50

varieties) $\ldots \ldots \ldots \ldots \ldots \ldots \ldots \ldots \ldots \ldots \ldots \ldots \ldots \ldots \ldots \ldots \ldots \ldots . .10 \quad .20 \quad .75 \quad 2.00$

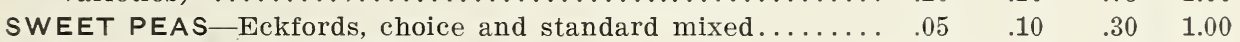

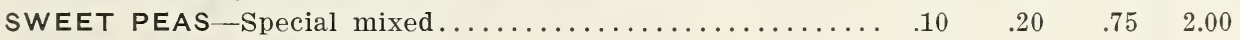

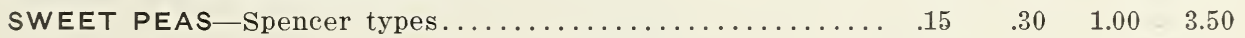

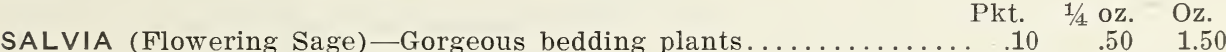

SALPIGLOSSIS-Useful for vases and table bouquets, special mixed,

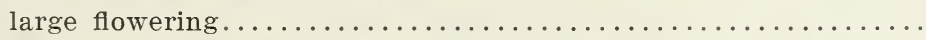

SCABIOSA (Mourning Bride)-Hardy annual; flowers beautiful

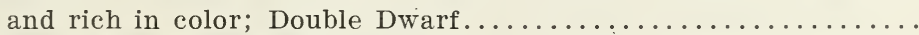

SENSITIVE PLANT--The leaves when touched instantly fold up;

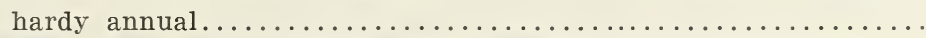

SILENE (Catch Fly) - Hardy annual; useful for beds and borders...

SWEET WILLIAM-Hardy perennial; beautiful and showy; single

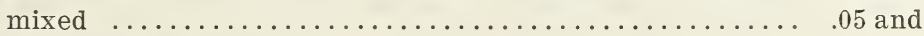

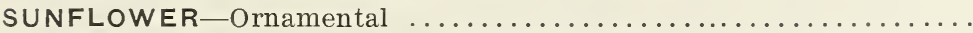

STOCKS-Hardy annual; for bedding, edging and pot culture, mixed

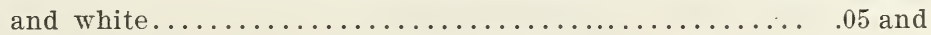

TASSEL FLOWER-Profuse flowering plant, with tassel shape

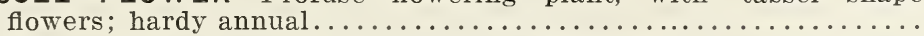

VENUS (Looking Glass)-Adapted for beds, baskets, vases and rock

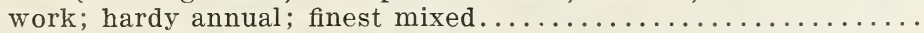

VERBENA-Mammoth mixed and white; Defiance brilliant scarlet.

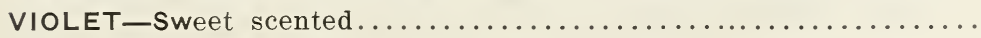

WALL FLOWER-Flowers fragrant, large spikes, profuse blooming;

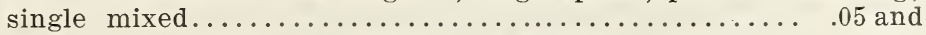

WILD FLOWER-Finest assortment of beautiful flowers in the wild

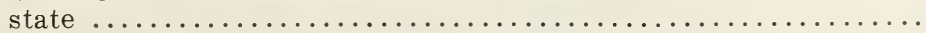

WHITLAVIA-Blue and white flowers, delicate foliage............

ZINNIA-Very showy annual, blooms early, remains late; Double

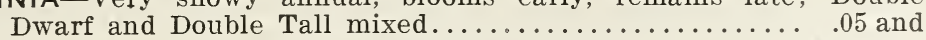




\title{
Descriptive Price List.
}

\section{Special Prices to Dealers, Market Gardeners and Large Consumers in Quantity Lots.}

\author{
ASPARAGUS \\ One Ounce to 50 Feet of Drill.
}

Sow the seed in the spring, as early as the ground will permit, in rows one foot apart. Soak the seed 24 hours in warm water, cover about $1 \frac{1 / 2}{2}$ inches and press the earth down by treading or rolling. Carefully hoe and keep from weeds. When two years old transplant to permanent beds, no base being required. Plow or dig the ground 9 or 10 inches deep. Set in rows 12 inches apart and 15 inches between the rows. Top dress the bed with three inches of old, well rotten manuure.

Every autumn the stalks should be rolled down, and in the spring top dressed with old, well rotten manure and sprinkle the bed with salt. Never use a fork on the bed, as it injures the crown. It should not be cut until the plants are three years old and then as near the surface as possible.

Lb. $1 / 4 \mathrm{lb} . \mathrm{Oz}$. CONOVER'S COLOSSAL................................. $\$ 0.60 \quad \$ 0.20 \quad \$ 0.10$

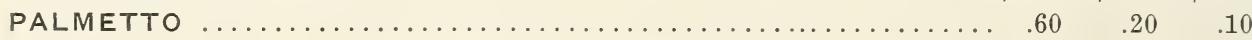

\section{BEANS}

One Quart to 100 Feet of Drill; 1 to $1 \frac{1}{2}$ Bushels to Acre in Drills.

Plant about the middle of May in a warm, dry spot in drills an inch deep and two feet apart, two inches apart in the drills, and cultivate when not wet. Keep hoed and kill the weeds. For succession, plant every two weeks.

Beans of nearly all kinds this year are next to complete failures.

\section{BUTTER OR WAX SORTS-DWARF VARIETIES}

IMPROVED GOLDEN WAX-Rust proof, pods long,

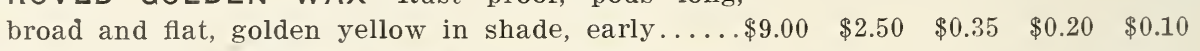

GOLDEN EYE WAX-Early, pods yellow, beans white

with golden eye.......................... 9.00

PROLIFIC BLACK WAX-Round yellow, stringless pods,

beans black........................... 8.50

DAVIS' WHITE KIDNEY WAX-Long, clear white pods,

beans kidney shape.......................... 9.00

WARDWELL'S KIDNEY WAX-Pods long, straight and

creamy white, seeds with dark spots.......... 9.50

HODSON WAX-New variety, long and tender........ 9.00

$2.50 \quad .35 \quad .20 \quad .10$

$\begin{array}{llll}2.25 & .35 & .20 \quad .10\end{array}$

$2.50 \quad .35 \quad .20 \quad .10$

$\begin{array}{llll}2.75 & .40 & .25 & .15\end{array}$

$\begin{array}{llll}2.50 & .35 \quad .20 \quad .10\end{array}$

\section{GREEN PODDED BUSH AND SNAP VARIETIES}

Burpee's Bush Lima-Type of large white Lima, dwarf

in growth............................. $\$ 9.50 \quad \$ 2.75 \quad \$ 0.40 \quad \$ 0.20 \quad \$ 0.10$

BURPEE'S STRINGLESS GREEN POD-Vine vigorous

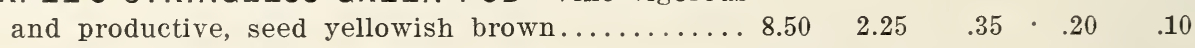

BROAD WINDSOR-True. English variety, large and

broad

9.00

2.50

.40 
DWARF ROYAL WHITE OR KIDNEY-An excellent

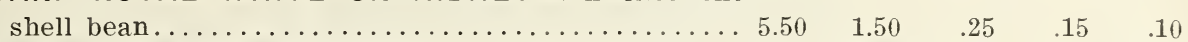
DWARF LARGE WHITE MARROW-Good for baking. $\begin{array}{lllll}5.50 & 1.50 & .25 & .15 & .10\end{array}$

LONG YELLOW SIX WEEKS-Early, long podded, one

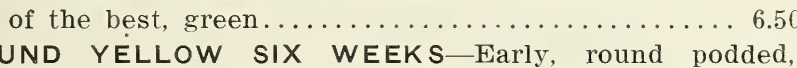
more fleshy than above..................... 7.00 REFUGEE OR 1000-TO-1 BEAN-Popular medium variety, grown for pickling................. 7.00

$\begin{array}{llll}1.75 & .25 & .15 & .10 \\ 2.00 & .30 & .15 & .10 \\ 2.00 & .30 & .15 & .10\end{array}$

\section{POLE OR RUNNING VARIETIES} One Quart to 50 Hills.

Pole Beans do best in sandy loam, enriched with short manure in the hills, which range from $3 \frac{1}{2}$ to 4 feet apart, with five or six beans planted eye downwards in each hill one inch deep. If warm and dry. plant about the 10 th of May for an early.crop and for the general crop a little later.

HORTICULTURAL OR CRANBERRY-Useful as a

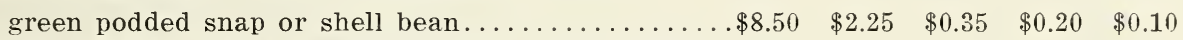

LARGE WHITE LIMA-Delicious shell bean, green or

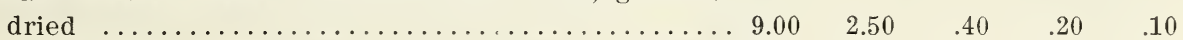

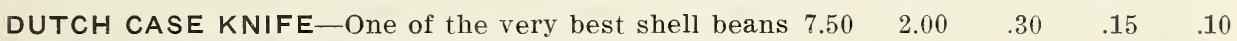
GOLDEN CLUSTER WAX-Pods 6 to 8 inches long in clusters $\ldots \ldots \ldots \ldots \ldots \ldots \ldots \ldots \ldots \ldots \ldots \ldots \ldots \ldots \ldots .9 .00 \quad 2.50 \quad .40 \quad .20 \quad .10$

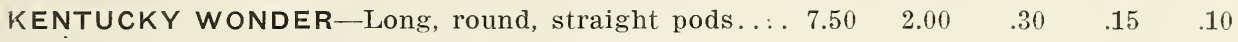

\section{BEETS}

One Ounce to 50 Feet Drill 5 to 6 Pounds to the Acre in Drills,

Sow in drill 14 to 16 inches apart, 1 inch deep, in light, rich soil, sandy loam being preferable, well manured with decomposed compost carefully worked in. For an early supply sow as soon as the ground can be worked; about the middle of May for general crop. When the plants are 3 inches high thin out to about 6 inches apart.

Lb. 1/4 lb. Oz. Pkt.

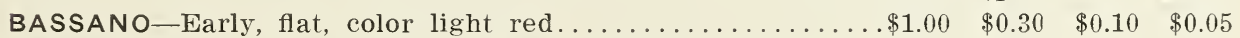

CROSBY'S EGYPTIAN-Early red turnip beet, the best of the

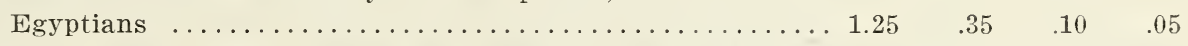

DETROIT DARK RED-Round skin, dark red, with light red

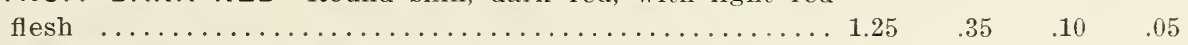

DEWING'S EA. BLOOD TURNIP-Turnip shape, small top,

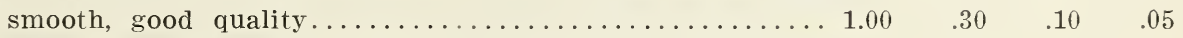

ECLIPSE-Very early, globe shape, glossy red flesh, sweet and

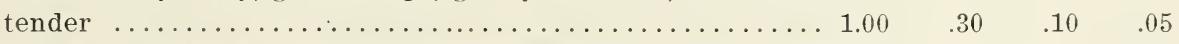

EARLY EGYPTIAN BLOOD-Very early, extremely dark, good

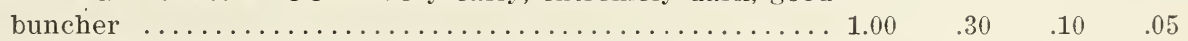

HALF LONG BLOOD-Good second early, good also for winter $\begin{array}{llll}1.00 & .30 & .10 & .05\end{array}$

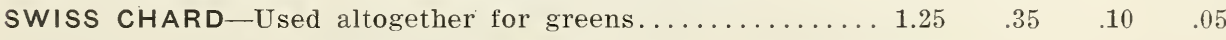

\section{MANGEL WURZEL AND SUGAR BEETS}

One Ounce to 50 Feet Drill; 6 to 8 lbs. to the Acre.

For Sugar Beets and Mangels make the rows $2 \frac{1}{2}$ to 3 feet apart and thin to 9 inches in the row.

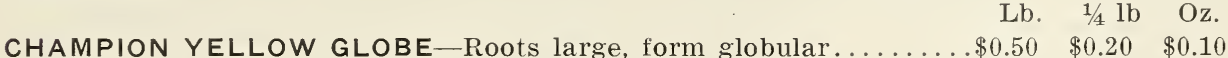

GOLDEN TANKARD_Color bright yellow, large and sweet....... $.50 \quad .20 \quad .10$

MAMMOTH LONG RED-Immense size, enormous yielder . . . . . . . $.50 \quad .20 \quad .10$

LARGE RED GLOBE-Globe shape, red, very productive........ .50 $\quad .20 \quad .10$

VILMORAIN'S SUGAR BEET-Used in manufacture of beet sugar. . $.50 \quad .20 \quad .10$

SLUDSTRUP - Cross between Long Red and Golden Tankard Mangel;

the best mangel ever grown.

$.60 \quad .25 \quad .10$ 


\section{BRUSSELS SPROUTS}

species of Cabbage. Cultivate same.

Dalkieth

Improved

Lb. 1/4 lb. Oz. Pkt. $\begin{array}{llll}\$ 1.75 & \$ 0.50 & \$ 0.20 \quad \$ 0.05\end{array}$ $\begin{array}{llll}1.75 & .50 & .20 & .05\end{array}$

\section{CABBAGE}

One Ounce to 3,000 Plants; $1 / 4$ to $1 / 2 \mathrm{lb}$. to Transplant to the Acre.

Sow early in hotbeds in February and March; transplant into rich manured ground about the middle of April. Ground should be well loosened up to make large heads. Hoe often to kill weeds and draw earth up to the stems. For late crops, sow in shallow drills 4 to 6 inches apart in April or May. To keep off the fly use soot, wood ashes, lime or tobacco dust; use freely early in the morning. One day's neglect may spoil the plants. Set during June in rich ground three feet apart.

EARLY JERSEY WAKEFIELD-Very early, heads cone shape

Lb. $1 / 4$ lb. Oz. Pkt.

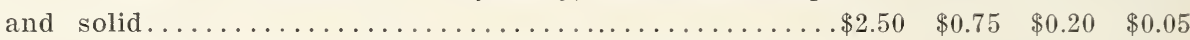

EARLY WINNINGSTADT-One of the best for either early or

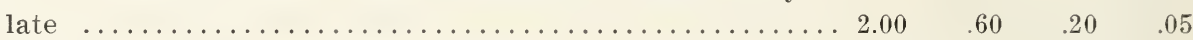

HENDERSON'S, EARLY SPRING-Earliest, round, flat-headed

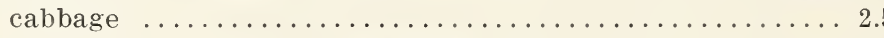

HENDERSON'S EARLY SUMMER-Large, solid, round, flat

heads, 10 days later than Wakefield .......................

HENDERSON'S SUCCESSION-Good either for summer or

uniform $\ldots \ldots \ldots \ldots \ldots \ldots \ldots \ldots \ldots \ldots \ldots \ldots \ldots \ldots \ldots \ldots \ldots . \ldots 3.00 \quad .90 \quad .30 \quad .10$

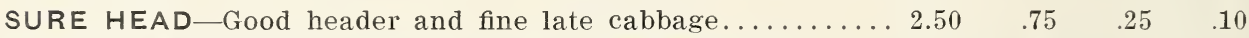

AUTUMN KING_Large heads and fine medium variety . . . . $2.50 \quad \begin{array}{llll}75 & .25 & .10\end{array}$

DANISH BALL HEAD, IMPORTED-Hard, solid, round heads,

a fine keeper.......................... $3.00 \quad .90 \quad .30 \quad .10$

FOTTLER'S BRUNSWICK-Large, solid heads, good for either

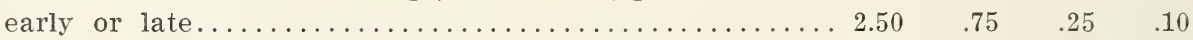

PREMIUM LATE FLAT DUTCH-A favorite winter variety . $\begin{array}{llll}2.00 & .60 & .20 & .05\end{array}$

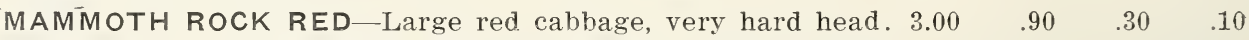

PERFECTION DRUMHEAD SAVOY-Crumple leaf cabbage,

superior flavor...........................2.5. $2.50 \quad .75 \quad .25 \quad .10$

JOHNSON'S MARKET GARDENER'S, NO. 2-The best of all

large early cabbage, about one week earlier than summer.

When planted late makes a good keeper for fall or winter. $\begin{array}{llll}3.50 & 1.00 & .30 & .10\end{array}$

DANISH ROUND HEAD-Type of Ball Head, but earlier,

rounded and heavier heads. Popular with gardeners . . . . $3.50,1.00 \quad .30 \quad .10$

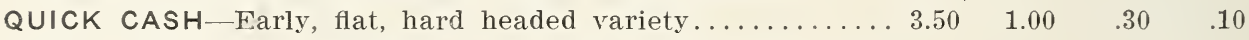

EARLY DANISH SUMMER-Three weeks earlier than late

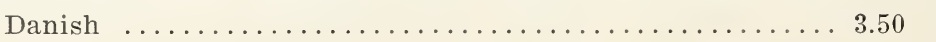

$1.00 \quad .30 \quad .10$

\section{CARROT SEED}

$1 \mathrm{Oz}$. to $125 \mathrm{ft}$. Drill; 3 to 4 Pounds per Acre.

CULTURE-Select a deep, sandy soil, made rich by manuring the previous year. For early table use sow as soon as the ground can be worked. For later crops, up to the middle of June. Plant in rows 15 to 18 inches apart, $1 / 2$ inch deep, pressing the earth down firmly. Thin out to 4 inches apart in the row. For field culture sow in drills 18 to 24 inches. Hoe often.

IMPROVED DANVERS' 1/2 LONG STUMP-General favorite with gardeners. dark orange color roots, 8 to 10 inches

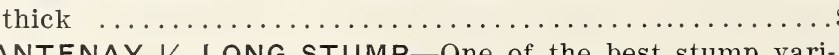

Lb. $1 / 4$ lb. Oz. Pkt.

HANTENAY $1 / 2$ LONG STUMP-One of the best stump vari-

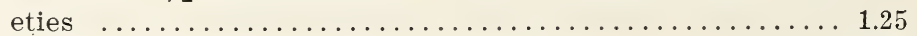

$\$ 0.40 \quad \$ 0.10 \quad \$ 0.05$

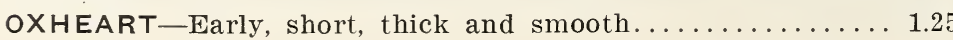

$.40 \quad .10 \quad .05$

$.40 \quad .10 \quad .05$ 
EA. SCARLET SHORT HORN-Very early, good forcing

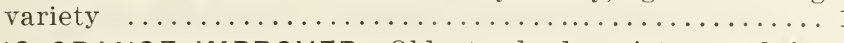

LONG ORANGE IMPROVED-Old standard variety, good for

LARGE WHITE BELGIAN-Cattle Carrot, large and produc-

IMPROVED SHORT WHITE-Roots short and thick, big

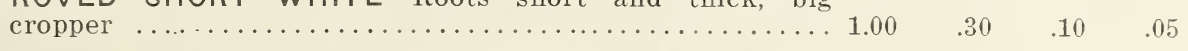

\section{CAULIFLOWER}

One Ounce for 3,000 Plants.

Should be sown in hotbeds in February, transplanted into another frame in the latter part of March, and in May planted out in rows 3 feet apart, 2 feet between plants. Any good cabbage soil will grow caulifiower, as their requirements are almost similar. If the weather is dry, water freely. The large leaves should be broken down over the flower head as they appear, to keep the sun and rain from injuring them. Can also be sown in the open ground during May and transplanted same as cabbage in July.

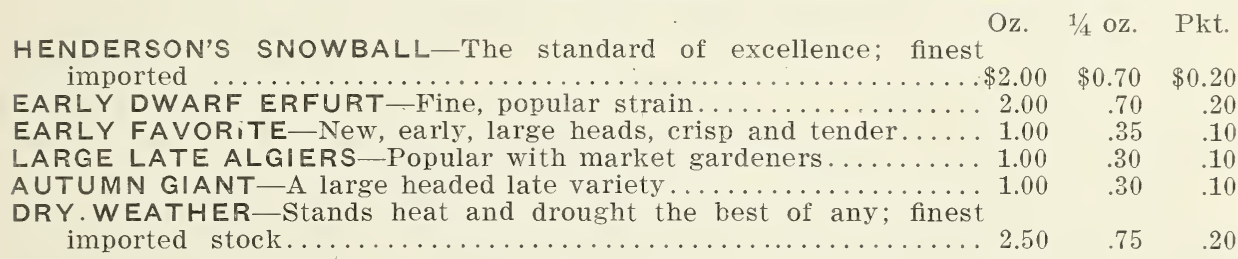

\section{CELERY}

\section{One Ounce Will Produce About 5,000 Plants.}

CULTURE-Celery thrives in a rich, mellow, moist, but not wet soil, and will do better in land well manured the previous season. For early use sow in hotbeds and prick out into cold frames until the ground is open, then transplant and crowd forward is rapidly as possible in order to get in condition for use before the hot weather, as it then becomes tough and pithy. For general crop, sow in seed beds or box, and transplant into cold frames. Transplant into rows four feet apart, setting the plants six inches apart in the row. Cultivate often. When nearly full grown gather the leaves together and draw the earth about them so as to hold them erect; after two or three days draw more earth around them, and repeat it every few days until nothing but the tops of the Jeaves can be seen. In doing this take care never to disturb the plants when wet, or allow earth to fall between the leaves, as it tends to rust.

HENDERSON'S WHITE PLUME-Very early, white, crisp,

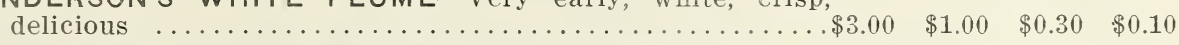

BOSTON MARKET-Solid, half round, green stalks, blanching

white, dwarf habit...............................

DWARF GOLDEN HEART-Large heart, solid stalks, crisp

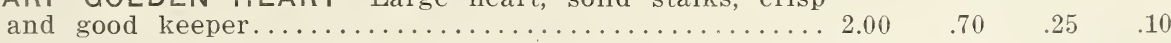

KALAMAZOO CELERY_Dwarf white, easily blanched . . . . $2.00 \quad 2.70 \quad .25 \quad .10$

IMPROVED GOLDEN SELF-BLANCHING-Early, stocky habit,

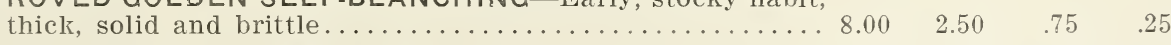

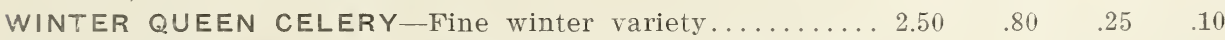

GIANT PASCAL-A good, long-keeping winter celery, with

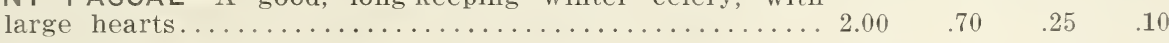

CELERIC_-Produces turnip-like roots, used for flavoring . . . $2.00 \quad .70 \quad .25 \quad .10$

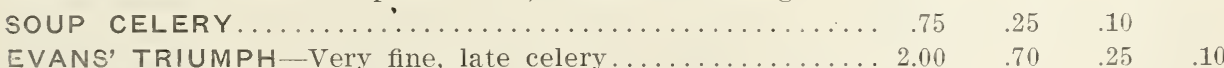

Celery plants in season.

\section{SWEET CORN}

One Pint to $100 \mathrm{Hills}$; One Peck to the Acre in Hills.

Plant about the middle of May, or as soon as the ground is dry (if planted too early, sorn is apt to rot; the late varieties are more liable to rot than the early ones), in hills 3 feet apart each way, 5 or 6 kernels in a hill. Hoe often and draw up the soil to the stems. Thin to 3 stalks and break off the side shoots. Use plenty of old, fine manure. For succession, plant every two or three weeks to the last of July. 


\section{EXTRA EARLY VARIETIES}

Special Prices in Large Quantity Lots.

WHITE COB COREY-Extremely early, fair size ears,

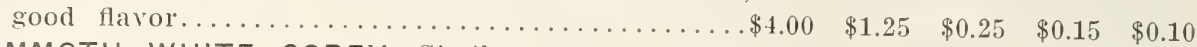

MAMMOTH WHITE COREY-Similar to above, but having larger ears. . . . . . .

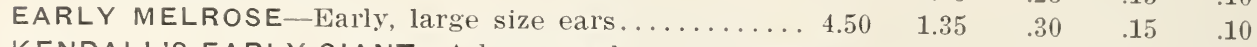

KENDALL'S EARLY GIANT-A large, early corn, sweet and tender.

PREMO-Large eared variety; claim to mature in 60

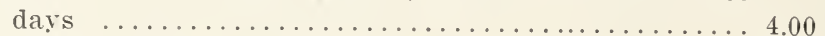

CHAMPION-Early, large ear, sweet and tender...... 4.00 METROPOLITAN-Very early, large eared variety.... 4.50 PEEP O' DAY - Extra early, very productive........ 4.00 GOLDEN BANTAM-Very early, yellow variety, sweet

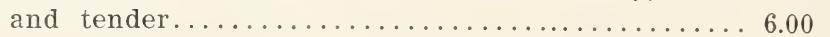

\section{SECOND EARLY}

CROSBY-Popular variety, ears about 7 inches long... 4.00 MINNESOTA-Standard variety, dwarf growth, between Corey and Crosby................. 4.00

BLACK MEXICAN-Medium early, bearing 8-inch ears. 5.00

EARLY EVERGREEN-10 days earlier than Stowell's Evergreen ...................... 4.00 PERRY'S HYBRID-Large, 12-rowed ears, a few days later than Minnesota ....................... 4.00
STABLER'S EARLY-Good second early, either for family use or canning................ 4.00 HENDERSON'S SUGAR CORN-Large ears, tender... 5.00

\section{LATE.}

COUNTRY GENTLEMAN-Kernels small, but extremely

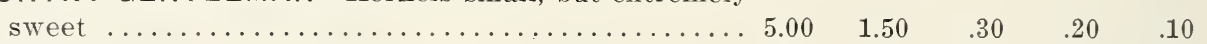

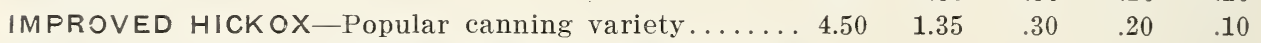
OLD COLONY-16 to 20-rowed, few days earlier than

Evergreen ........................... 4.00 STOWELL'S EVERGREEN-Very large ears, with large,

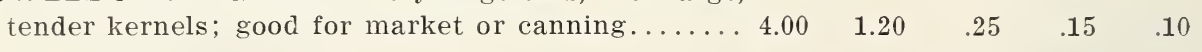

\section{PEDIGREE ENSILAGE AND FIELD CORN}

The cheapest corn you can plant out, as it is selected for vitality, growth and productiveness.

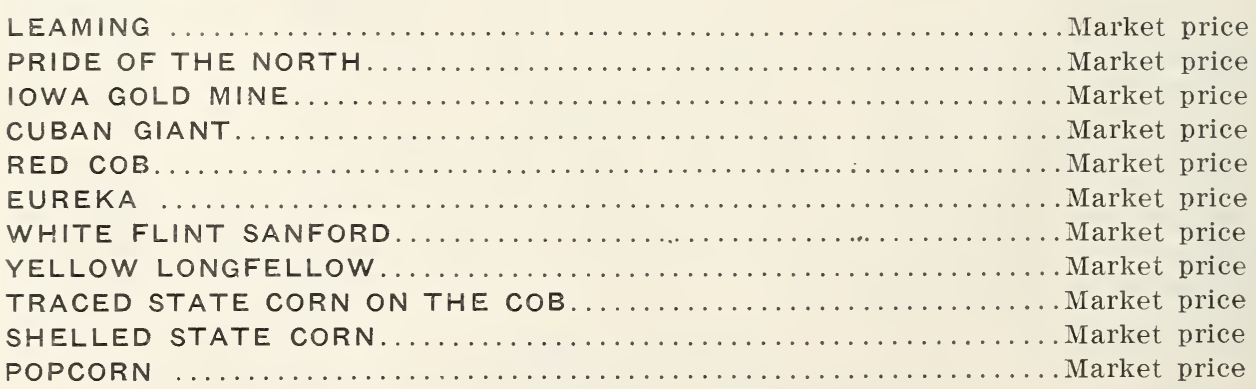

\section{CUCUMBER}

One Ounce to 50 Hills; $2 \frac{1}{2}$ to 3 lbs. to the Acre in Hills.

For main crop, plant the seeds in open ground, as soon as the weather becomes warm and settled, in hills four feet apart, using a shovelful of warm, well-rotted manure to each hill. Cover manure with two inches of fine earth, and plant eight or ten seeds 
in each hill. Cover these with one-half inch of soil well pressed down. Hoe often, and when out of danger of insects, thin out to three or four plants in a hill. Fruit should be plucked when large enough, whether required for use or not, for if left on the vines it destroys their productiveness.

EARLY CLUSTER-Fruit small, borne in pairs, color light Lb. $1 / 4 \mathrm{lb}$. Oz. Pkg.

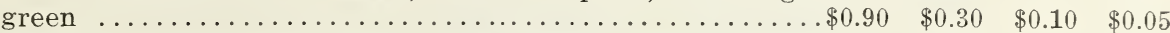

GREEN PROLIFIC-Form small and brittle, good pickling

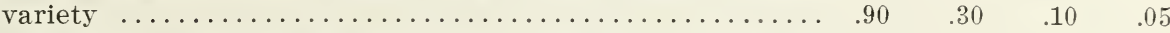

IMPROVED WHITE SPINE-Early; good for slicing or pickles; popular market sort; extra selected.......... $.90 \quad .30 \quad .10 \quad .05$

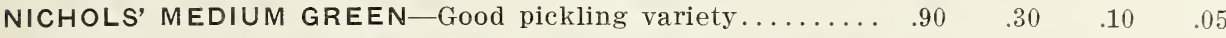

IMPROVED LONG GREEN-Good pickler when small; when $\begin{array}{lllllll}\text { grown makes large yellow slicers; extra selected . . . . . . . } & .90 & .90 & .10 & .05\end{array}$

FORDHOOK PICKLING_One of the best for medium pickles $\begin{array}{llll}1.00 & : 40 & .15 & .05\end{array}$

DAVIS' PERFECT-Long, slim, dark green; good for forcing. . $\begin{array}{llll}1.00 & .40 & .15 & .05\end{array}$

\section{CHICORY}

Cultivate like carrot. Roots, when dried, roasted and ground, used as substitute for coffee. LARGE ROOTED............................ \$1.00 $\$ 0.35 \quad \$ 0.10 \quad \$ 0.05$

Lb. $1 / 4 \mathrm{lb} . \quad \mathrm{Oz} . \quad \mathrm{Pkg}$.

\section{CORN SALAD OR FETTICUS}

One Ounce to 20 Square Feet.

Sow in drills $1 / 2$ inch deep and 12 inches apart, the latter part of August or in September. Tread in the seed lightly if the weather is dry. Keep free from weeds and cover thinly with straw or leaves just before winter. Makes a fine salad or can be cooked like spinach.

LARGE GREEN-Used as a substitute for lettuce in winter

Lb. $1 / 4$ lb. Oz. Pkg.

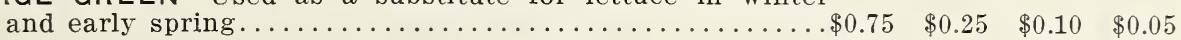

\section{CRESS}

One-half Ounce to 100 Feet of Drill.

Sow thickly in shallow drills about 1 foot apart every two or three weeks for salad. Can be cut three or four times. Water Cress requires a stream of water, in which it will grow without care, except at first keeping the weeds from interfering with it.

EXTRA CURLED-Used for salads and garnishings ........ $\begin{array}{llll}\text { Lb. } & 1 / 4 \mathrm{lb} . & \text { Oz. } & \text { Pkg. }\end{array}$ TRUE WATER CRESS-Grows in water; fine salad. . . . . . . $3.50 \quad 1.00 \quad .35 \quad .10$

\section{EGG PLANT}

One Ounce to 1,000 Plants.

Sow thickly in hot-bed, and if possible prick out, that they may become stocky. When about four inches high set out, thirty inches apart each way, in good rich soil, when the weather has become warm and settled.

N. Y. IMPROVED PURPLE

Lb. $\quad 1 / 4$ lb. Oz. Plig. .$\$ 4.00 \quad \$ 1.25 \quad \$ 0.40 \quad \$ 0.10$

\section{ENDIVE}

One-half Ounce to 100 Feet of Drill.

CULTURE-Sow from late in the spring to the middle of summer in shallow drills fourteen inches apart; thin the plants to one foot in the drills and when fully grown and the plants are dry, tie over the outer leaves to blanch the center ones. This will require from ten to twenty days.

Lb. 1/4 lb. Oz. Pkg.

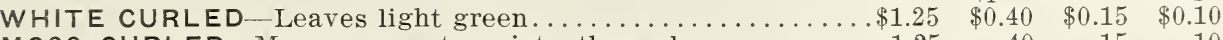

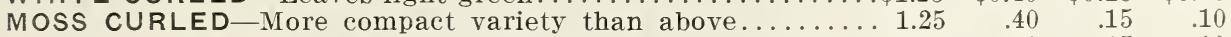

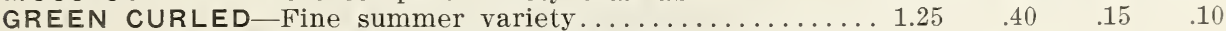

BROAD LEAF BATAVIAN-Large heads, leaves broad and

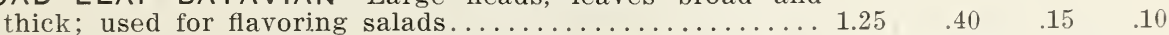

\section{KALE OR BORECOLE}

One Ounce to 150 Feet of Drill.

The richer the soil the more abundant the crop. Sow from the middle of April to the middle of May in prepared bed, covering seeds thinly and evenly; transplant in June, and treat in the same manner as cabbage. 
DWARF GREEN CURLED SCOTCH Ised for greens, also for Lb. $1 / 1 \mathrm{lb}$. Qt. Pkg.

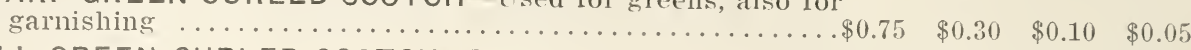

TALL GREEN CURLED SCOTCH-Leaves dark green, curled

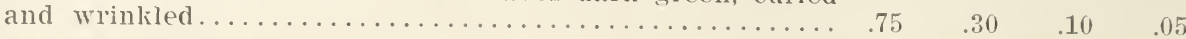

\section{KOHL-RABI OR TURNIP-ROOTED CABBAGE}

\section{One-half Ounce to 100 Feet of Drill.}

Half way between a turnip and cabbage, partaking of the nature and flavor of both. Sow from April to Jume; plant and cultivate the same as cabbage. Set out in drills 18 inches apart and 18 inches in the drill.

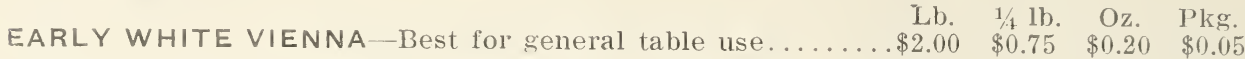
EARLY PURPLE VIENNA-Little later than white, color

bluish purple.................................

\section{LEEK}

One Ounce to 100 Feet of Drill.

Sow early in spring, in drills 16 to 18 inches apart, and thin to 6 inches.

BROAD AMERICAN FLAG-Very large; most popular market

Lb. $\quad 1 / 4$ lb. Oz. Pkg.

variety

$\$ 1.75 \quad \$ 0.50 \quad \$ 0.20 \quad \$ 0.10$

\section{LETTUCE}

One Ounce to 200 Feet of Drill.

CULTURE-For early plants sow the seed in September, and transplant into cold frames during the winter, or sow in February or March in hot-beds with moderate heat; cover lightly and thin enough to prevent crowding. In April transplant in the open ground, set in rows a foot apart and 6 inches apart in the row. When heads begin to form, thin out by using alternate plants in the row. For general crop sow outdoors in the spring as early as the ground can be worked, in drills 18 inches apart, and thin out to 4 inches in the row. For succession, plant at intervals of two weeks during the season.

\section{HEAD VARIETIES.}

BIG BOSTON-Desirable forcing variety, large, solid heads, extra selected........................ \$1.50

IMPROVED HANSEN-Heads large, solid, fine quality . . . . . 1.25 WHITE SUMMER CABBAGE-Large heading summer variety 1.25 ICEBERG (NEW) - Good size head, leaves green, slightly

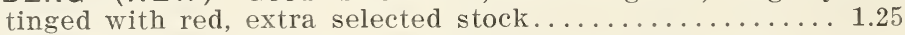

SALAMANDER-Heads large, compact tender; great heat and

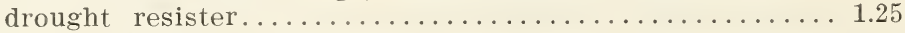

YELLOW SEEDED BUTTER-Large, dense, yellow headed

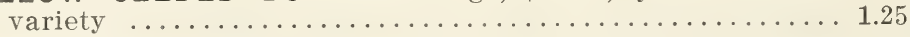

MAY KING-For early planting; round, solid. green heads;

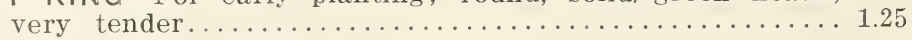

BROWN DUTCH-Leaves large, thick, tinged with brown,

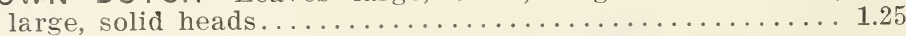

DENVER MARKET-Leaves like Savoy Cabbage.......... 1.25

\section{CURLED OR LOOSE HEADED VARIETIES}

EARLY CURLED SIMPSON-Early, for forcing or open

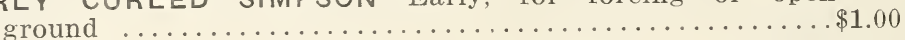

GRAND RAPIDS-Loose heads; in good demand as a forcing or shipping lettuce; extra selected stock............ 1.25 BLACK SEEDED SIMPSON-Large, loose heads, light color.. 1.25 COE'S SELF BLANCHING-Long, narrow leaves, folded into loose heads; can be blanched by drawing the outer leaves

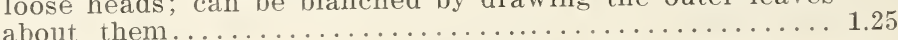

EARLY PRIZE HEAD-Large, loose heads, tinged with brown 1.25

1/4 lb. Oz. Pkg.

$\$ 0.50 \quad \$ 0.15 \quad \$ 0.05$

$.40 \quad .15 \quad .05$

$\begin{array}{lll}.40 \quad .15 & .05\end{array}$

$.40 \quad .15 \quad .05$

$.40 \quad .15 \quad .05$

$.40 \quad .15 \quad .05$

$.40 \quad .15 \quad .05$

$\begin{array}{lll}.40 \quad .15 & .05\end{array}$

$\begin{array}{lll}.40 & .15 & .05\end{array}$

1/4 1b. Oz. Pkg.

$\$ 0.35 \quad \$ 0.15 \quad \$ 0.05$

$.40 \quad .15 \quad .05$

$\begin{array}{lll}.40 & .15 & .05\end{array}$

$.40 \quad .15 \quad .05$

$\begin{array}{lll}.40 \quad .15 & .05\end{array}$

NEW TRIANON COE'S OR CELERY LETTUCE-LEaves when bleached are stiff like celery sorts........... 1.50

ONONDAGA. MARKET-Fine for early forcing, also for

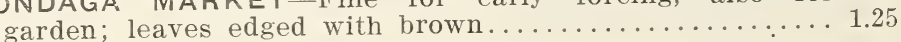




\section{MUSHROOMS}

Mushrooms produce no seeds, but instead there is developed a white fibrous substance in broken threads, called spawn, which is developed and preserved in horse manure pressed in the form of bricks.

CULTURE-Mushrooms can be grown in a cellar, in sheds, in hot beds, or sometimes in the open air, or out-of-the-way places. Fermenting horse manure at a temperature of about 70 degrees, mixed with an equal weight of fresh sod loam, is made into beds the size required, eight to twelve inches deep. See to it that the bed is packed firmly and evenly. In this bed plant the broken pieces of spawn six inches apart, covering the whole with two inches of light soil, and protect from cold and rain. One brick will plant eight to ten square feet of bed. The mushrooms will appear in about six weeks. Water sparingly and with lukewarm water.

I can furnish reliable mushroom spawn at any time.

\section{MUSKMELONS}

One Ounce to 60 Hills; 3 lbs. to Acre.

CULTURE-For melons a light, sandy, rich soil is best. When the ground has become warm and dry, plant in hills 6 feet apart each way, 8 to 10 seeds in a hill. Mix in a shovel of well-rotten manure in each hill. When danger from insects has passed pull up all but three plants. Pinch the ends of the vines to hasten early fruiting. Sifted ashes, air-slacked lime and dry road dust sprinkled over the plants when the dew is on will prevent attacks of insects. The weather very largely affects the quality of melons.

GOLDEN NETTED GEM-Shape nearly round, color dark green and thickly netted...................\$1.00 \$0.35 $\$ 0.10 \quad \$ 0.0$.

SURPRISE-Shape round, skin cream colored, heavily netted,

flesh salmon color............................... $\quad .00 \quad .10 \quad .05$

IMPROVED HACKENSACK-Large fruit, round and heavily netted, flesh thick and fine..................... $45 \quad .25 \quad .10 \quad .05$

MILLER'S CREAM-Round, color dark green, finely netted, flesh salmon pink............................... $1.00 \quad .25 \quad .10 \quad .05$

ROCKYFORD-Improved oblong form of Netted Gem, green flesh $\ldots \ldots \ldots \ldots \ldots \ldots \ldots \ldots \ldots \ldots \ldots \ldots \ldots \ldots \ldots \ldots \ldots \ldots .75 \quad .25 \quad .10 \quad .05$

EMERALD GEM - Very sweet, medium size, salmon color . . . $1.00 \quad .35 \quad .10 \quad .05$

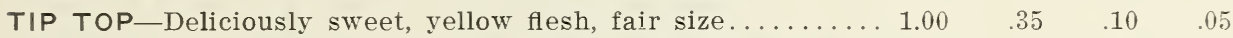
IRONDEQUOIT-Nearly round, flesh deep orange, good size. $\begin{array}{rrrr}1.50 & .50 & .20 & .10\end{array}$ PAUL ROSE-Early, nearly round, salmon flesh, fine keeper. . $\begin{array}{lllll}1.50 & .50 & .20 & .05\end{array}$

\section{WATERMELONS}

\section{One Ounce to 25 Hills; 4 to $5 \mathrm{lbs}$. to an Acre.}

CULTURE-In order to get good watermelons it is essential that the plants get a good start, and to this end it is important to prepare hills about eight feet apart, by thoroughly working into the soil an abundance of well-rotted manure, and in this plant the seed as soon as the ground becomes warm and dry.

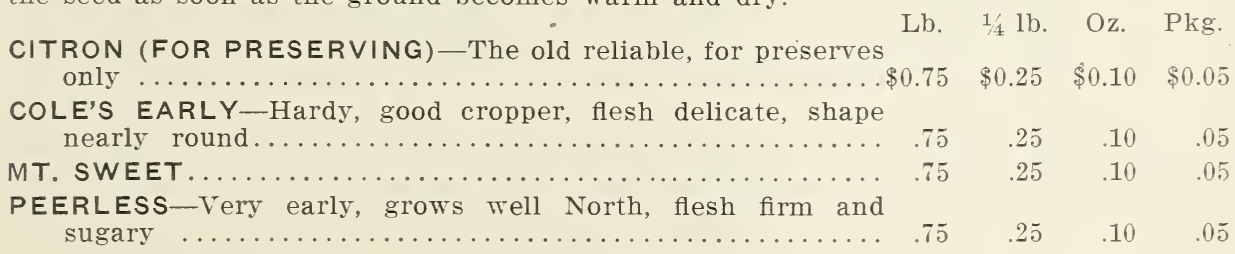

\section{ONIONS}

Special Prices in Large Quantity Lots.

One Ounce to 100 Feet of Drill; 5 to 6 Pounds in Drills to the Acre.

Onions should be sown in drills, 1 inch deep and 12 to 16 inches apart, in rich, loamy soil, deeply dug and lightly rolled. It is better to have land that has been used for hoed crops for a year or two and has been well manured. If the requisite amount of manure is put on all at once it is apt to make the bulbs soft. If manured gradually 
the land cannot be made too rich. The manure, however, should not be rank, but shoukd be well fermented. Ground bone or superphosphate may be used, but if they are, they should be well applied, partly when the crop is sown and partly as the bulbs hegin to form. It is advisable to use a seed drill in planting, first testing the regulator upon a floor to see if it allows the seeds to pass out in proper proportion. From 5 to 6 pounds to the acre is usually sown. If the drill used has no roller, a hand roller should be passed over the ground immediately after sowing. As soon as the onions are up so that the rows can be seen, they should have the first hoeing, just skimming the ground between the rows. After a few days they should be hoed close up to the plants and weeded, and in two weeks another hoeing and weeding should be given.

(Best Quality Eastern Grown Seed.)

Lb. 1/4 lb. Oz. Pkg.

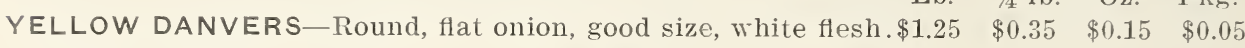

YELLOW GLOBE DANVERS-Globe shape, small top, very

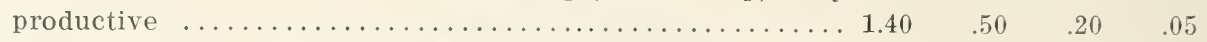

MICH. YELLOW GLOBE DANVERS-A great favorite with

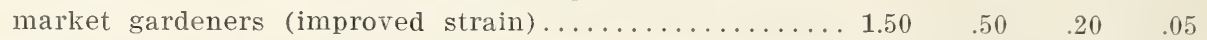

PRIZE TAKER-Large globe, uniform in size, mild in flavor,

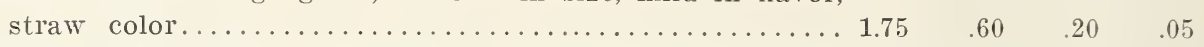

RED WETHERSFIELD-Large, fine grain, skin deep purplish

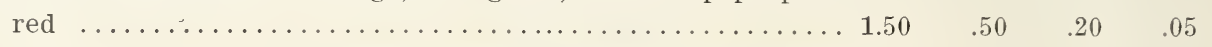

SOUTHPORT WHITE GLOBE_Clear white skin, large fine

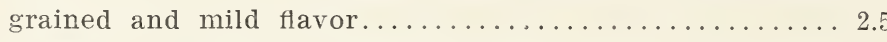

SOUTHPORT YELLOW GLOBE-Bright yellow skin, globe-

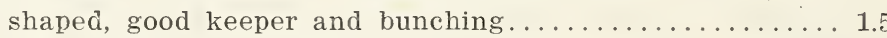

WHITE QUEEN-Small, mild flavored, grown for sets, also

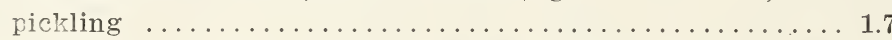

MAMMOTH SILVER KING-Immensely large, pure silvery

white skin, mild in flavor; largest flat onion grown.....2.00

AUSTRALIAN BROWN-Globe shape, brown onion, a splendid

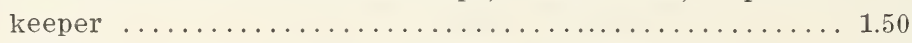

WHITE PORTUGAL OR SILVERSKIN-Best for sets....... 1.75

PHILADELPHIA YELLOW GLOBE-Popular market variety. 2.00

ONION SETS

One Quart to 50 Feet Drill; 8 to 10 Bushels to Acre.

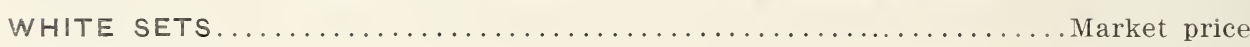

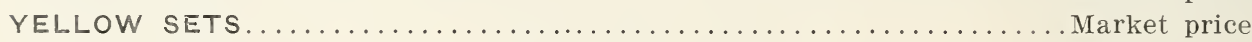

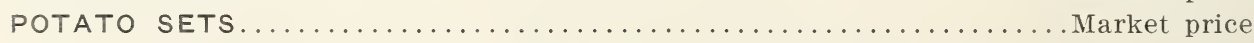

\section{PARSNIPS}

Orie-Half Ounce to 100 Feet of Drill; 5 to 6 Pounds to the Acre in Drills.

Sow in drills one-half inch deep and 15 inches apart, after the ground has become thoroughly warmed, otherwise seed may rot. When plants are two or three inches high, thin out to six inches in the row. Hoe frequently. Soil should be rich and deep, well pressed or rolled. Take up what you may need for winter use and store in cellar; leave the rest in the ground until spring, where they keep better and become tender and sweet.

Lb. $1 / 4 \mathrm{lb}$. Oz. Pkg.

HOLLOW CROWN-A general favorite with gardeners......\$0.75 $\$ 0.25 \quad \$ 0.10 \quad \$ 0.05$ LONG SMOOTH DUTCH-Roots run long, smooth and white. $\quad \begin{array}{llll}.75 & .25 & .10 & .05\end{array}$

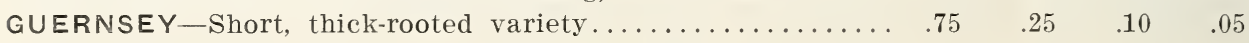

\section{PARSLEY}

\section{One Ounce to 150 Feet of Drill.}

Sow early in the spring in drills one foot apart, covering half an inch deep, in a rich soil. Thin plants to four inches apart, when two inches high. As the seed germinates very slowly, three or four weeks sometimes elapse before it makes its appearance. It is good to soak the seed in lukewarm water before sowing. To preserve in winter, take out the plant and treat like celery. 
Lb. $1_{4} 1 b$. Oz. Pkg. MOSS CURLED_Fine curled rariety. dark green in shade . . \$1.00 \$0.40 \$0.15 $\$ 0.05$ DOUBLE CURLED-Dwarf in habit, crimped leaves........ $1.00 \quad .40 \quad .15 \quad .05$ TRIPLE CURLED-Similar to abore, but more dense in

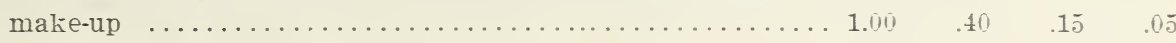
FERN LEAF-Largely used for decorating............ $1.00 \quad .40 \quad .15 \quad .05$

\section{PEAS}

Special Prices in Large Quantity Lots

CLLTCRE-For early peas the soil should be light and warm. but for general crop a moderately heary soil is better. Soil that is freshly manured. rery rich or wet and mucky should be aroided, as it causes a rank growth of vine at the cost of the quality of the peas; such soil is often the cause of early sorts maturing unerenly. As early in the spring as the ground can be worked. sow in double rows six to ten inches apart, the pairs being two or four feet apart, according to height of rine. The seed should be planted in a furrow two and a half or three inches deep. but not corered with more than an inch of soil, particularly if the ground is heary. The peas should be gathered as fast as they become fit for use. If eren a few pods begin to ripen, new pods will not only cease to form, but those partly adranced will stop growing.

EXTRA EARLY

One Quart to 100 Feet of Drill; 2 to 3 Bushels to Acre in Drills.

FIRST AND BEST-Tery early, old standard tarietr. B. Bu. Pk. Qt. Pt. Plit.

ALASKA-Earliest of the blue pea rarieties........ $5.50 \quad 1.50 \quad .25 \quad .15 \quad .10$

GRADUS OR PROSPERITY-Earliest large wrinkled pea grown, pods extremely large, peas sweet and

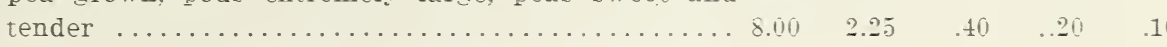

THOMAS LAXTON-Similar to Gradus, but darker and more productive........................ $8.00 \quad 2.25 \quad .40 \quad .20 \quad .10$

LAXTONIAN-Extreme early; large pods...........50 $9.50 \quad 2.50 \quad .50 \quad .25 \quad .15$

\section{DWARF EXTRA EARLY VARIETIES}

AMERICAN WONDER-Earliest dwarf rariety, delicious flaror........................

MCLEAN'S LITTLE GEM-Good rielder, popular for

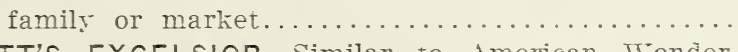

NOTT'S EXCELSIOR-Similar to American Wonder, more prolific................... 7.00

PREMIUM GEM - Extra early, fine flavor.......... 7.00

SUTTON'S EXCELSIOR-Early, large pods........ 7.50

LITTLE MARVEL-Very early dwarf variety........ 7.50

\section{SECOND EARLY}

MCLEAN'S ADVANCER-Old standard rariety, good

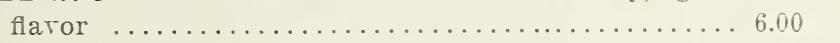

DUKE OF ALBANY-Pods of immense size, similar to Telephone, but earlier and of superior quality.....6.60

DWARF CHAMPION-Good rielder, peas large and fine

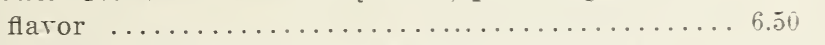

HEROINE-Pods large and long, peas of delicious flator 6.00

IMPROVED TELEPHONE-This is a decided improrement orer the old Telephone pea, in growth, quality

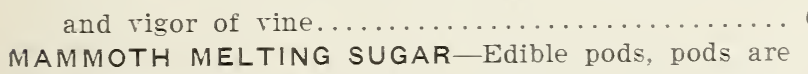

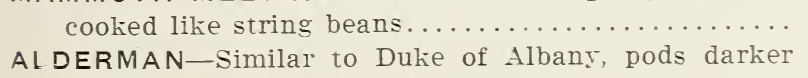

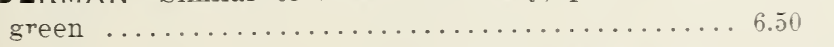

$\begin{array}{llll}1.75 & .30 & .15 & .10 \\ 1.75 & .30 & .15 & .10 \\ 1.75 & .30 & .20 & .10 \\ 1.75 & .30 & .15 & .10\end{array}$

\section{LATE VARIETIES}

CHAMPION OF ENGLAND-Old standard variety, im-

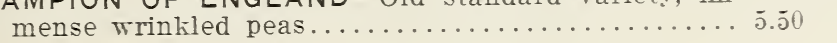




\section{PEPPER}

One Ounce for 1,500 Plants, or One-Half Pound to Acre.

Sow in hot-bed in March and transplant to open ground in a light, warm soil, when danger from frost is past. When three inches high, transplant to eighteen inches apart each way: hoe often.

LARGE BELL OR BULL NOSE-Large early variety, mild

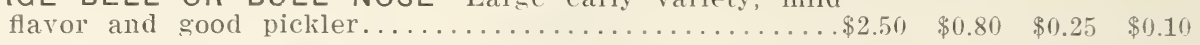

LONG RED CAYENNE-Late variety, strong and pungent,

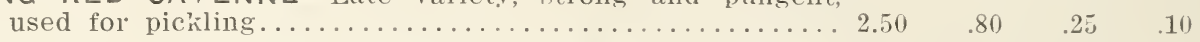

RUBY KING-Large, red, mild flavor, for stuffing and salads . $2.50 \quad 20 \begin{array}{lll}2.50 & .25 & .10\end{array}$

SWEET MOUNTAIN OR MAMMOTH-Resembles Bull Nose,

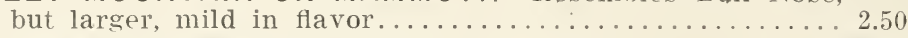

CHINESE GIANT_Extra large size, very mild........ 4.00

$\begin{array}{lll}.80 & .25 & .10 \\ 1.25 & .35 & .15\end{array}$

\section{PUMPKIN}

One Pint to 100 Hills; 4 Pounds to the Acre.

Cultivate same as squash, or plant in the spring amongst field corn. Avoid planting near other vines.

CONNECTICUT FIELD-Large field variety, for Lb. $1 / 4 \mathrm{lb.} \quad \mathrm{Oz.}$ QUAKER PIE_-Oval in shape, color creamy white........... .60 $\quad .20 \quad .10$

WINTER LUXURY_Round golden yellow, good for pies . . . . . . . $.60 \quad .20 \quad .10$

\section{RADISH}

French grown stock-the best on the market.

One Ounce to 100 Feet of Drill; 8 to 10 Pounds per Acre in Drills.

Sow early varieties in the spring, as early as the ground can be worked, in drills ten inches apart, covering the seed half an inch deep; thin the plants to an inch apart in the rows. As they are more succulent and tender when grown quickly, a rich, moist, sandy soil should be selected, and frequently water in dry weather. For a succession, sow every two weeks till midsummer.

\section{SPRING AND SUMMER}

EARLY SCARLET TURNIP FORCING-Small round red turnip shape, mild, crisp......................... $\$ 0.70 \quad \$ 0.25 \quad \$ 0.10 \quad \$ 0.05$

PRUSSIAN GLOBE-Round deep red radish, liked by gar-

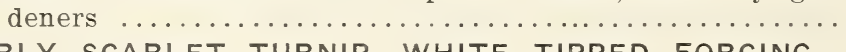

EARLY SCARLET TURNIP, WHITE TIPPED FORCING-

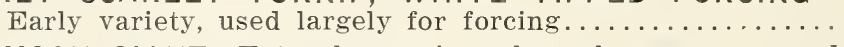

CRIMSON GIANT-Extra large size, shape between a round and oval, very tender and mild flavor, selected stock......

LARGE WHITE SUMMER TURNIP_-Crisp and mild........

GIANT WHITE STUTTGART-Large white summer, tender

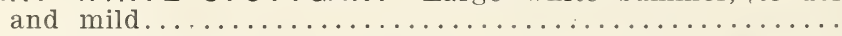

OLIVE SHAPED EARLY SCARLET-Skin bright scarlet, flesh

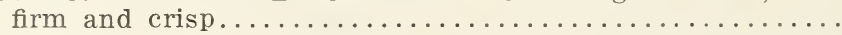

VICK'S SCARLET GLOBE-Very early, an excellent forcing

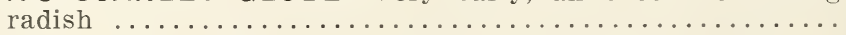

FRENCH BREAKFAST-Olive shaped, red with white tip....

LONG BRIGHT SCARLET-Very bright scarlet, white tip, crisp

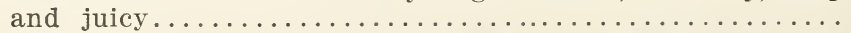

CHARTIER-Long summer radish, crimson top with white tip

LONG SCARLET SHORT TOP_-Bright scarlet root and small

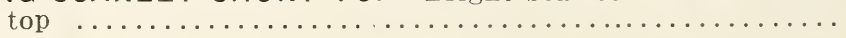

WHITE STRASBURGH-A popular summer variety, pure

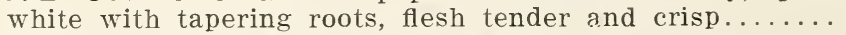

NON PLUS ULTRA-Bright red, fine forcing variety......... .

WHITE ICICLE-Long clear white, short leaves, extra fine.. .70

SCARLET BUTTON-Round, bright scarlet, very early..... .7

CARDINAL GLOBE-Bright scarlet, extra early.............7

WHITE LADY'S FINGER-One-half long variety, tender and

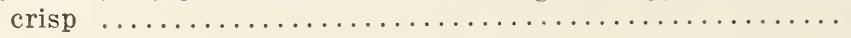

\begin{tabular}{|c|c|c|}
\hline .70 & .25 & .10 \\
\hline .70 & .25 & .10 \\
\hline .70 & .25 & .10 \\
\hline .60 & .20 & .10 \\
\hline 60 & .20 & .10 \\
\hline .60 & .20 & .10 \\
\hline .70 & .25 & .10 \\
\hline .70 & .25 & .10 \\
\hline 60 & .20 & .10 \\
\hline 60 & .20 & .10 \\
\hline .60 & .20 & .10 \\
\hline 70 & .25 & .10 \\
\hline 70 & .25 & :10 \\
\hline .70 & .25 & .10 \\
\hline 70 & .25 & .10 \\
\hline .70 & .25 & .10 \\
\hline & .25 & .10 \\
\hline
\end{tabular}




\section{WINTER RADISHES}

CULTURE-While quick growth is not so essential for these as for the earlier sorts, they do best on a rich soil which has keen made as fine and friahle as possible. Sow late in spring or early summer in rows 18 inches apart and thin the plants to four to eight to the foot. They may be pulled as wanted through the fall, and on the approach of severe freezing weather should be harrested, part paclec in damp sand and stored in a cool cellar or other easily accessible, cool place for wintc: use, and the balance buried in the ground as one would bury potatoes for spring use,

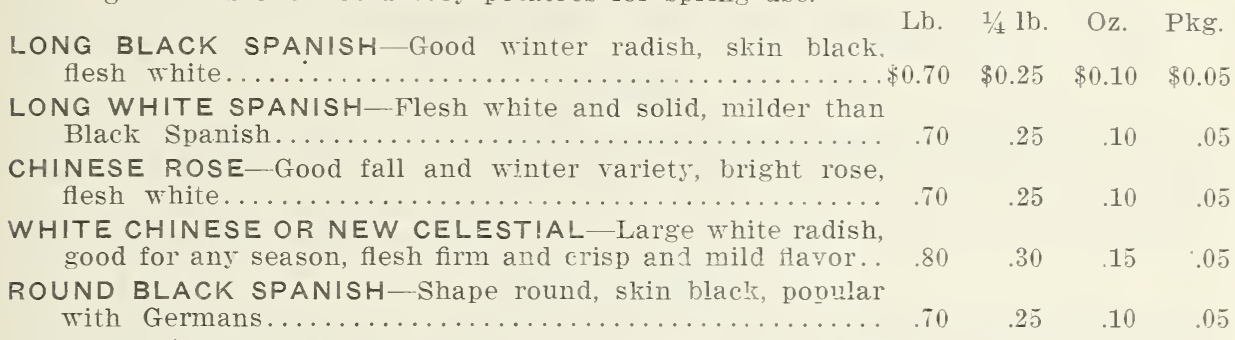

\section{SALSIFY, OR VEGETABLE OYSTER \\ One Ounce to 75 Feet of Drill.}

Sow as early as the ground can be worked in the spring, in a light, mellow soil, which should be stirred to a depth of 18 inches; sow in drills 12 inches apart, one inch deep, and thin out to four or five inches in a row. Keep clear from weeds. Cultivate the same as the parsnip.

MAMMOTH SANDWICH ISLAND-Extra large roots, superior

$$
\text { Lb. 1/4 lb. Oz. Pkg. }
$$

in quality and flavor to the other kinds (selected stock) $\ldots \$ 1.25 \quad \$ 0.40 \quad \$ 0.15 \quad \$ 0.05$

\section{SPINACH}

Special prices to Market Gardeners and Others in Quantity Lots.

One Ounce to 100 Feet of Drill; $8 \mathrm{lbs}$, in Drills and 12 lbs. Broadcast to Acre.

For summer use sow early in the spring, in deep, rich soil, well manured, in drills one foot apart, covering the seed one inch deep. For very early spring use, sow in August, and protect the plants through the winter with a covering of leaves or straw. For a succession, sow at intervals of two weeks.

BLOOMSDALE, SAVOY LEAVED-Leaves crimped and dark green;

an early variety; also good for fall planting. . . . . . . . . . $\$ 0.25 \quad \$ 0.10 \quad \$ 0.05$

THICK LEAF ROUND-Leaves large, thick and crinkled, color dark

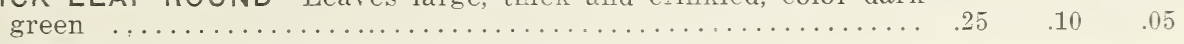

VICTORIA-Very dark green color, fine quality, does not run to seed

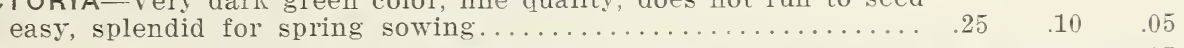

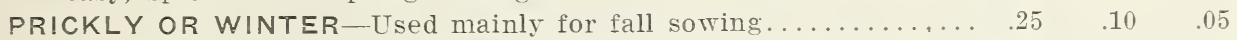

L.ONG STANDING THICK LEAVED-Thick, dark green leaves, slow

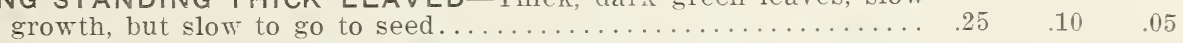

NEW ZEALAND-New variety, distinct in itself, stands the heat of

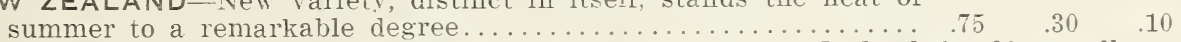
I will sell 5 lbs. of any of the above Spinach, except New Zealand, for $20 \mathrm{c}$ per $1 \mathrm{~b}$.

\section{SQUASH}

Bush Squash, One Ounce to 50 Hills; 5 to $6 \mathrm{lbs}$, to Acre.

Running Squash, One Ource to 20 Hills; 3 to 4 lbs. to Acre.

Prepare the ground by thoroughly pulverizing it. Nanure highly. All vines delight in warm and rich soil. Plant in hills 9 to 10 feet apart for running varieties, 5 to 6 feet for bush sort, working some fine, rich manure into each hill. Plant eight or ten seeds and when out of danger of bugs, leave only two plants to the hill. Keep well covered with plaster or air-slacked lime in the early stages of growth. Cultivate till runners are well started. WHITE BUSH SCALLOP_Early, fine flavor. . . . . . . . . . \$0.75 $\$ 0.25 \quad \$ 0.10 \quad \$ 0.05$

Lb. 1/4 lb. Oz. Pkg.

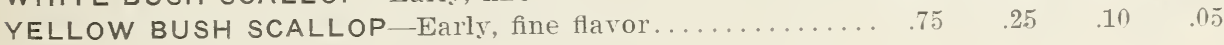



MAMMOTH SUMMER CROOKNECK An darly large variety
of the Summer. Clookneck, early and of fine quality......

GOLDEN SUMMER CROOKNECK-The standard summer

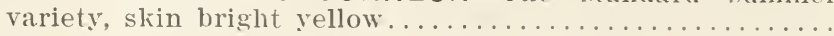

BOSTON MARROW-Early fall variety, bright orange, shape

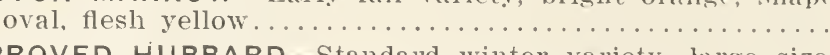

IMPROVED HUBBARD - Standard winter variety, large size, flesh fine and close grained, a splendid keeper...........

MAMMOTH CHILI-Extremely large, color yellowish orange;

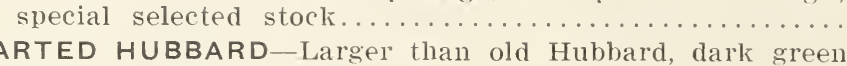

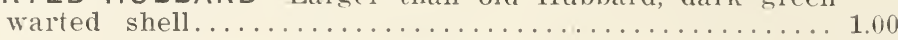

Lb. $1 / 4$ 1b. Oz. Pkg. $.75 \quad .25 \quad .10 \quad .05$ $\begin{array}{llll}.75 & .25 & .10 \quad .05\end{array}$ $\begin{array}{lll}.85 & .30 \quad .10 \quad .05\end{array}$ $\begin{array}{llll}1.00 & .35 \quad .10 \quad .05\end{array}$ $\begin{array}{llll}1.25 & .40 & .15 \quad .10\end{array}$ GOLDEN HUBBARD Same as Hubbard except color. . . . . . 1.00 FORDHOOK WINTER - Bright yellow, sweet and dry ....... 1.00 DELICIOUS-Late variety; green skin, flesh orange, very meaty ............................. 1.00

\section{SUNFLOWER}

LARGE RUSSIAN-Extensively used for feeding poultry. This is much superior to the common sort, as it forms a single, large flower, and the seeds are larger and richer in oil. On account of war conditions in Europe Sunflower seed has materially advanced.

\section{TOBACCO}

CULTURE-The seed should be sown as early as possible after danger of frost is over. A good plan is to burn a quantity of brush and rubbish in the spring on the ground intended for the seed bed, then dig and thoroughly pulverize the earth and mix with the ashes, after which the seed may be sown and covered very lightly. When the plants are about six inches high, transplant into rows four or five feet apart each way and cultivate thoroughly with plow and hoe.

CONN. SEED LEAF-Best adapted to climate of Middle and Northern Oz. Pkg.

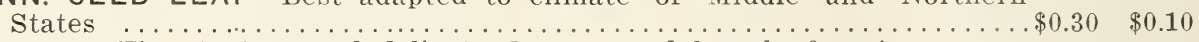
HAVANA-Fine texture and delicate flavor; used largely for cigar wrap-

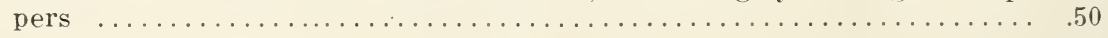

\section{TOMATO}

One Ounce to Produce 3,000 Plants; 2 Ounces Will Produce Plants Enough for an Acre. Sow in hot-beds in March. Transplant to open ground when the weather becomes warm and settled, or sow in open ground in May, and transplant when plants are six inches high. The richer the soil, the more handsome and plentiful the fruit; but to have the fruit ripen as early as possible, select rather light, poor soil and a sunny location. Plant in hills, four feet apart each way. After the fruit is set, pinch off the ends to check growth, gradually strip off leaves to expose the fruit to sun.

High Grade, Selected Stocks.

SPARK'S EARLIANA--Largest of the extreme early tomatoes, Lb. $1 / 4$ lb. Oz. Pkg. color brilliant red, solid, with few seeds. Seed from

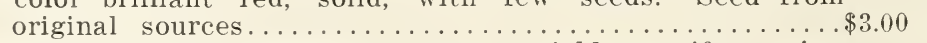

CHALKS' EARLY JEWEL-Enormous yielder, uniform size,

comes after Earliana. Seed from original sources...... $3.00 \quad .90 \quad .30 \quad .10$

MAULE'S EARLIEST-Very early, large size, solid, good quality. Seed from original sources.............. 3.00

EARLY RUBY - Very early, large size, good yielder........ 2.00

DWARF CHAMPION-Dwarf in habit; early, medium size

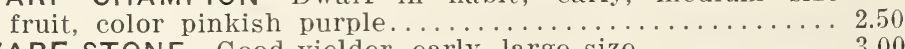

DWARF STONE - Good yielder, early, large size............ 3.00

LIVINGSTON'S FAVORITE-Large, smooth, good shape

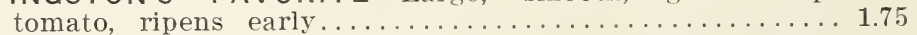

CRIMSON CUSHION-Immense size, smooth, almost seedless

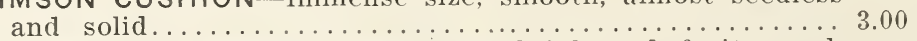

LIVINGSTON'S PERFECTION-Early, bright red, fruit round,

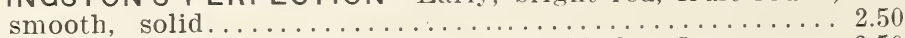

MATCHLESS-Very large, red, smooth, solid, fine flavor....... 2.50

NEW STONE-Favored by canners, fruit round, solid, neaty, color bright scarlet. Ranks among late varieties....... 2.50

LANDRETH'S RED ROCK-Excellent shipper. In great de-

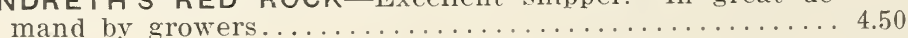

$\$ 0.90 \$ 0.30 \quad \$ 0.10$

$.90 \quad .30 \quad .10$

$.60 \quad .20 \quad .05$

$\begin{array}{lll}.75 & .25 \quad .10\end{array}$

$\begin{array}{lll}.90 & .30 & .10\end{array}$

$.60 \quad .20 \quad .05$

$.90 \quad .30 \quad .10$ 
JUNE PINK TOMATO-Seed from original sources. A pink

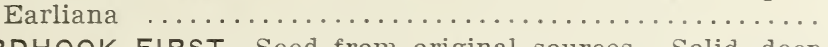

FORDHOOK FIRST-Seed from original sources. Solid, deep

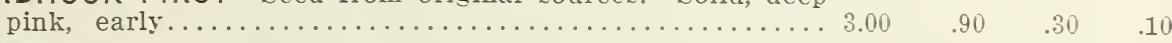

TREE

Lb. $1_{ \pm}$lb. Oz. Pkg.

$3.00 \quad .90 \quad .30 \quad .10$

PLUM-Used for preserves, bright lemon color $\ldots \ldots \ldots \ldots$

PEAR-Yellow, pear shaped............................

RED CHERRY_Little fruit, bright scarlet................

GOLDEN QUEEN-Large yellow, smooth tomato; ripens early

\section{TURNIP}

On account of the scarcity Turnip seed has advanced ovel last rear.

I oz. to $150 \mathrm{ft}$. Drill; $1 \frac{1}{2}$ to 2 lbs. in Drills to the Acre; 2 to 3 lbs. to Acre Broadcast.

For early use, sow as soon as the ground can be worked in the spring, in drills 14 inches apart, covering but slightly, except in dry weather. The soil should be light, and, if possible, new. Nanure with plaster, ashes or phosphate. Thin the early varieties to six inches apart, and the Rutabagas to one foot. For fall and winter use the early kinds should be sown in July and August, and Rutabagas through June and July. Hoe them a month after sowing.

EARLY WHITE FLAT DUTCH-Standard, early white turnip, good garden variety, flesh white and mild............\$0.60 $\$ 0.20 \quad \$ 0.10 \quad \$ 0.05$

PURPLE TOP STRAP LEAF-Good for garden or field use, shape round and flat, color white with purple top......

PURPLE TOP WHITE GLOBE-Large globe shape, white with purple top, sweet and tender, good for stock or garden...

WHITE EGG-A good table turnip, for early or late use, sweet

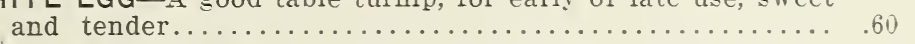

EARLY WHITE MILAN-Extra early, tender and delicious... 1.00

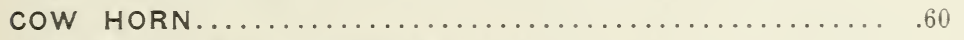

GOLDEN BALL OR ORANGE JELLY-Early, golden yellow,

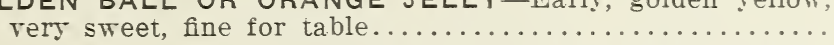

\section{RUTABAGA OR SWEDE TURNIPS}

WHITE SWEET GERMAN-The sweetest of all table turnips, solid as a stone and also a good keeper for winter........

WHITE FRENCH-Standard white Rutabaga, hard and sweet

YELLOW SWEDE-Standard yellow Rutabaga, hard and sweet

LONG ISLAND PURPLE-Fine variety of Rutabaga, skin and

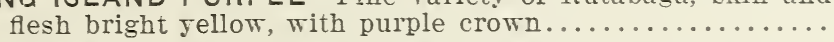

Special prices in quantity lots to dealers, market gardeners and large consumers.

Please bear in mind that you can get no better seed for growth and vitality than I am offering you from any source whatever.

\section{AROMATIC, MEDICINAL AND POT HERBS}

CULTURE-Herbs require rich, mellow soil. Sow seeds in shallow drills early in spring, one foot apart; when up a few inches thin out, or transplant. Cut them on a dry day before blossoming, tie in bunches and hang up, or spread thinly on a floor where they can dry quickly.

Lb. $1 / 4 \mathrm{lb}$. Oz. Pkg.

ANISE-Aromatic, used for seasoning............... \$1.00 \$0.30 \$0.10 \$0.05

BALM-For balm tea and also wine...................... $2.25 \quad .70 \quad .25 \quad .10$

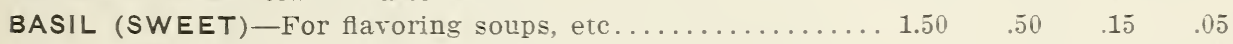

CARAWAY-For flaroring bread, pastry, etc............... $\quad .75 \quad .25 \quad .10 \quad .05$

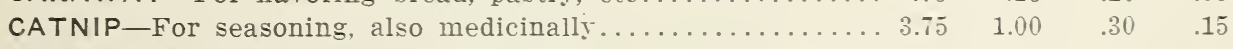

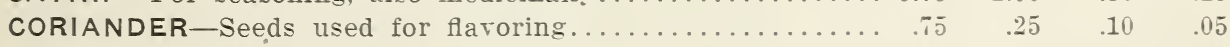

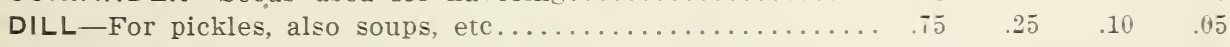

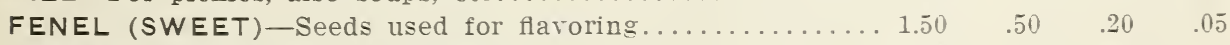

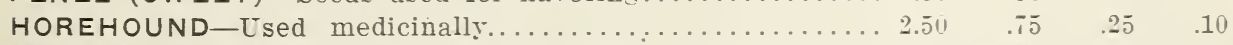

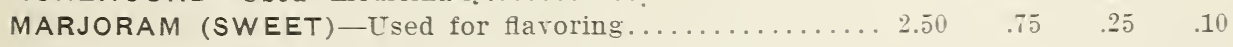

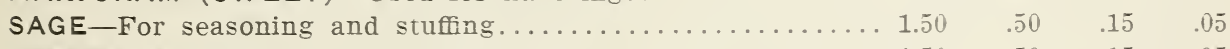

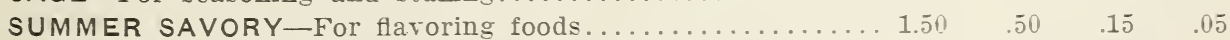

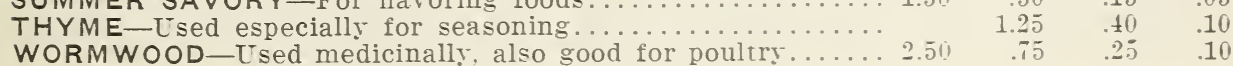




\title{
FLOWER SEEDS OF ALL KINDS
}

\author{
Sweet Peas, Nasturtiums, Bulbs, Canary and Parrot Seed. \\ Plant Foods, Bone Meal, and Sheep Manure for Plants. \\ Cabbage, Tomato, Cauliflower, Pepper, Aster and Pansy Plants in Season \\ FARM SEEDS
}

ALFALFA OR LUCERNE-The most valuable of all the clovers. Grown largely as a forage plant. It is one of the most nutritious of foods for horses or cattle. It requires a rich and well-drained soil. It is a great drought resister, as it has a tendency to root very deep. When thoroughly set it can be cut three or four times in one season. It should be sown in well-prepared and deeply plowed soil at the rate of 25 to 30 lbs. per acre broadcast, 20 lbs. drilled. It should be cut when the plant is coming into bloom. The Alfalfa $I$ sell is government tested and guaranteed free from trefoil and dodder: Weight, 60 lbs. to bushel.

ALSIKE-Here is a clover that does well in cold, stiff soils and marshy lands where other clovers would fail. It can also withstand severe cold. In appearance it resembles both the red and white clovers, but is far more hardy than either. It is an enormous yielder and particularly valuable for sowing with other clovers and grasses. Sow in spring or fall at the rate of $8 \mathrm{lbs}$. per acre when used alone. Weight, $60 \mathrm{lbs}$. per bushel.

CRIMSON CLOVER-Valuable for feeding green and also for hay. It is a fine soiling crop and particularly valuable for turning under. Sow in spring or summer at the rate of 12 to $15 \mathrm{lbs}$. to the acre if used alone. Sixty lbs. per bushel.

RED CLOVER-The best known farm crop for soiling, hay or for turning under as green manure. If used alone sow at the rate of 8 to 12 lbs. per acre. Sixty lbs. per bushel.

WHITE DUTCH CLOVER-A dwarf variety of a creeping nature, resisting extremes of heat and cold, but prefers moist ground. It is valuable in permanent pastures and affords most excellent feed for cattle and sheep. It is also used largely in lawn grass mixtures. Sow at the rate of $8 \mathrm{lbs}$. to the acre if used alone. Sixty lbs. to bushel.

TIMOTHY-The best known and most valuable of the hay grasses. Particulariy ndapted to moist, loamy or clayey soils, and not so well suited to light, sandy soils. It should be cut when flowering. I shall keep the best Western grades, also State Timdhy. Sow at the rate of one-half bushel to the acre if used alone.

KENTUCKY BLUE GRASS-One of the best known native grasses. Succeeds in almost any soil, dry, rocky, sandy, or gravelly. Will stand protracted dry weather and lot suns. It makes a most valuable pasture grass, and it is highly esteemed in lawn srass mixtures. Sow at the rate of 3 bushels to the acre for pasture or meadow. Weight, 14 lbs. to bushel.

RED TOP-A hardy giass. Does the best on moist soils. Good for low, wet meadows, but can adapt itself to dry conditions. It is permanent in its nature and in good demand for pasture mixtures. Chaff Red Top runs $14 \mathrm{lbs}$. to the bushel; use three bushels to the acre if sown alone. Fancy Recleaned Red Top runs 32 lbs to the bushel; use $20 \mathrm{lbs}$. to the acre if sown alone.

ORCHARD GRASS-One of the best grasses for permanent meadows. It is hardy, yields well and makes good hay. It makes good feed either dry or green, and stock of all kinds are fond of it. It stands the shade well, but should never be sown on lawns. If used alone sow $2 \frac{1}{2}$ to 3 bushels to the acre. Weight, $14 \mathrm{lbs}$. to bushel.

RAPE (DWARF ESSEX)-Makes an excellent feed for sheep, also a good soiling plant. Sow in May, or it may be sown in June or July. If sown in drills, 3 lbs. to the acre. If sown broadcast, $5 \mathrm{lbs}$. to the acre.

SORGHUM-EARLY AMBER SUGAR CANE--Ripens wherever Indian corn matures. This belongs to the saccharine class, as does the Early Orange Sorghum, but the Early Amber Sorghum does best in the Middle and Northern States. If sown in drills $10 \mathrm{lbs}$. to the acre; broadcast, 18 to $20 \mathrm{lbs}$.

I carry in stock a line of Seed Barley, Oats, Rye and Wheat, on which I expect to meet the market for the same quality of goods. 
JONES' IMPERIAL LAWN GRASS - This mixture is made up of the finest and most permanent grasses especially adapted to lawns, and as the seeds are free from chaff this mixture will run $20 \mathrm{lbs}$. to the measured bushel. Use 1 quart to 200 square feet, or 4 to 5 bushels per acre.

I can also furnish the original Batchelor's Lawn Grass Mixture, as I bought out the good will of the Batchelor Seed Store.

I can also furnish the following Grass Seeds if necessary: Rhode Island Bent Grass, Pacey's English Rye Grass, Tall, Hard, Meadow, and Sheep Fescues, Crested Dogstail, Meadow Foxtail, Sweet Vernal Grass, Batchelor's Meadow and Pasture Mixtures.

\section{ENSILAGE AND FIELD CORNS}

My specialty is pedigreed stock, selected with greatest care from seed of highest vitality. In buying corn, buy the VERY BEST you can get. Don't let a few cents stand in the way of your having a successful crop. If necessary, I can furnish you something cheaper, but would advise, BY ALL MEANS to get the BEST. I expect to meet the market for the same quality of goods. I make a specialty of the following brands:

PEDIGREE LEAMING-A yellow dent corn in great demand. Thick stock, heavy foliage, ears long, kernels deep orange in color, with small cob. Matures in three or four months' time.

PEDIGREE PRIDE OF THE NORTH-Also a yellow dent variety. This does not run to stock like the Leaming, but more to ears. Matures in three or four months' time.

PEDIGREE CUBAN GIANT-The largest of all the ensilage corns. Grows to an immense size, with extra large ears.

PEDIGREE RED COB ENSILAGE-Grows tall, with plenty of leaves. Kernels pure white with red tips, sweet and tender.

PEDIGREE MASTODON-This is another of the large eared, yellow dent varieties.

In the Flint varieties I sell the YELLOW LONGFELLOW and WHITE SANFORD STATE CORNS and GOLDEN HARVEST AND EUREKA CORN, also STATE CORN on the ear.

\section{MILLETS, SOILING CROPS, ETC.}

BILLION DOLLAR GRASS-Have you tried it? Valuable for forage, also for silo, as it makes excellent fodder. Grows from 6 to 7 feet high, producing 10 to 12 tons per acre. Sow 8 quarts to the acre.

GERMAN MILLET-This is the kest known of all the Millets. Strong and vigorous in growth, bright golden color. A good crop for both soiling and hay. Ready to cut in two months' time from sowing. Sow from $3 / 4$ to 1 bushel to the acre.

HUNGARIAN MILLET-Known as Hungarian Grass. Can be sown in June for a second crop. Matures in about 60 days. Does best on light soils; is a good heat and drought resister. Sow 1 bushel to the acre broadcast.

SIBERIAN MILLET-A native of Russia. The berry shades to a dull red. Largely used as a chicken feed. The forage is well liked by stock in general. Sow at the rate of $1 / 2$ bushel to the acre.

BUCKWHEAT, SILVER HULL-Clump berry, silver gray in color. An improvement over the common kind. It matures sooner, keeps in bloom longer, and yields nearly double the quantity per acre. Sow at the rate of $3 / 4$ bushel to the acre. Fortyeight pounds to the bushel.

BUCKWHEAT, JAPANESE--Large grain, dark brown in color. Matures early. Great yielder. Makes excellent flour.

COW PEAS-Grown largely in the South; also grown North as a fodder plant. Especially valuable as a green crop to plow under, as it is a great fertilizer. The seed should not be sown lefore the ground is well warmed. Sow broadcast at the rate of $1 \frac{1}{2}$ to 2 bushels to the acre.

CANADA FIELD PEAS--One of the best of soiling crops, also good for green manure. They do better where they are sown with oats, rye or barley. Sow in March or April at the rate of $1 \frac{11}{2}$ to 2 bushels to the acre.

SOJA OR SOY BEANS-Good for fodder or as a fertilizer. This is cultivated similar to corn, planted in hills and harvested with the corn binder. To make a finer hay, however, sow broadcast and mow with a mower. They can also be sown with the Cow Peas. When sown in hills, sow at rate of 1 peck to the acre. When sown broadcast, sow at rate of $1 \frac{1}{2}$ bushels to the acre. 


\section{IRON AGE Garden Drills and Wheel Hoes}

No. 6

Price $\$ 12.00$

No. 6 includes all tools.

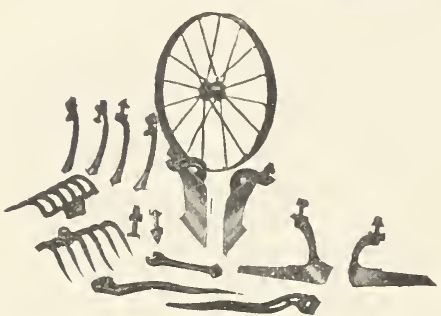

small lever changes the drill instantly from one form to the other. Has force feed with brush agitator that does not injure the seed.

Its wheel hoe form is known as No. 1 -it is shown here as double or single wheel hoe, and is changed quickly from one form to the other. Hoes astride the row or between the rows without injury to the plants. Will cultivate, weed, ridge, open

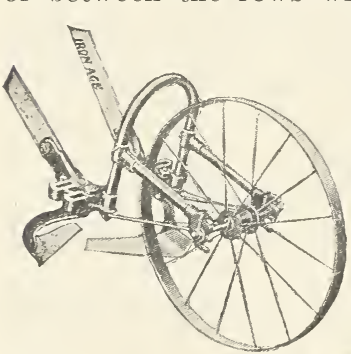

furrows and cover them, level and pulverize the soil etc. Has 16-inch steel wheels that ride the holes and furrows easily, steel tube frame, best scouring hoes on any tool of the kind. time saved and more accurate planting. Sows all kinds of small seeds in continuous rows or drops in hills at any reasonable distance apart. A

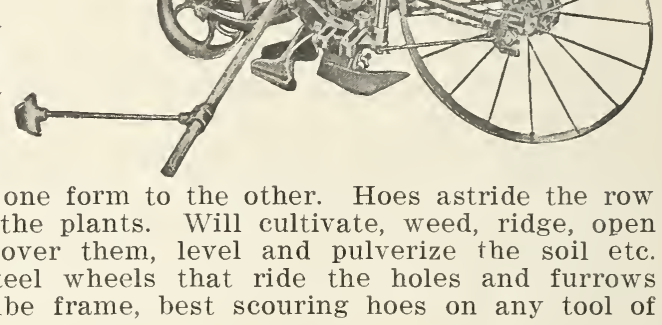

No. 3

Price \$4.25, with side hoes only.

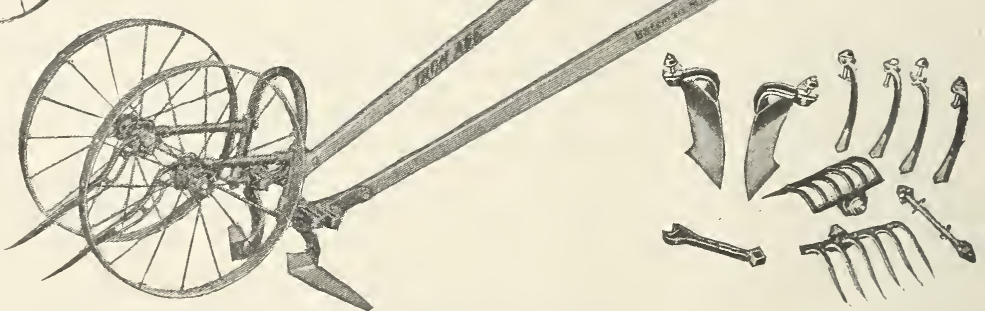
one-a drill seeder, a hill dropper, a double wheel hoe and a single wheel hoe. A practical tool for every day use and it soon pays for itself in the

No. 1, Complete with all tools, $\$ 7.00$.

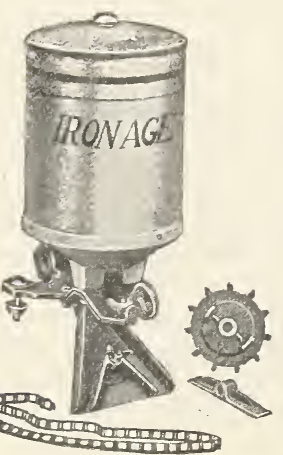

NO. 25 OR 26 FERTILIZER ATTACHMENTS can be applied to No. 1 wheel hoe frame. No. 25 will handle any commercial fertilizer-sows across the bottom or at either side in the furrow, or as a side dresser to force growing crops. No. 26 drills the fertilizer after making its own furrow, covers and packs it and marks the next row.

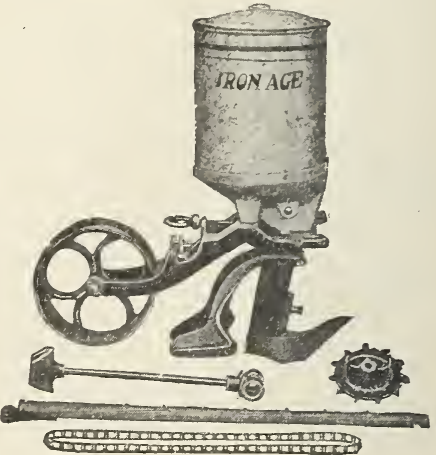




\section{IRON AGE Drill and Wheel Hoes}

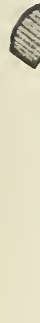
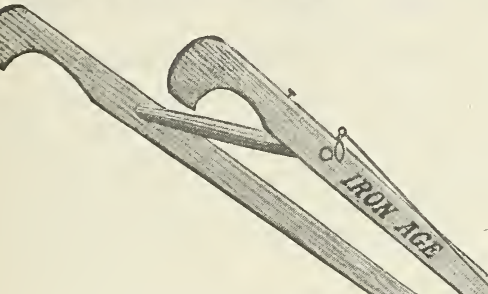

Here is shown No. 18-B-it is a combination of Iron Age No. 20 Wheel Hoe and No. 4 drill attachment with special plow that makes a narrow furrow, for onions, for instance-cuts out needless hand weeding. Does the same work as No. 6, but cannot be used as a double wheel hoe. Price, as a drill only, $\$ 7.50$. If wanted with cultivating tools, order 17-B. Price $\$ 10.00$. No. 20 Single Wheel hoe, price $\$ 6.00$.

No. 10 Single Wheel Hoe is in the simplest form, to be used between rows, and is invaluable to onion grow.ers and others, because you can get close to the plants without injuring them. Price $\$ 3.25$. No. 9 is the complete form of this tool. Price $\$ 5.25$.

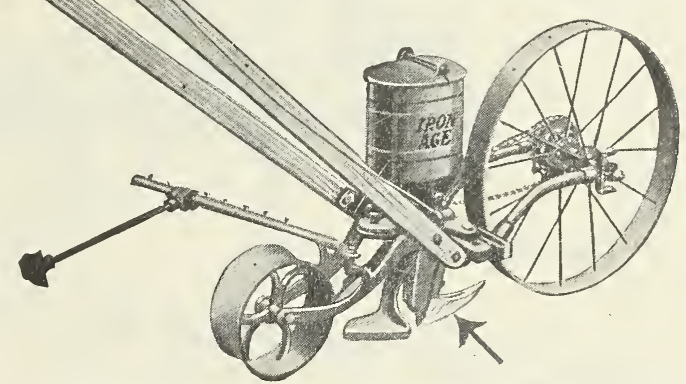

No. 18-B

Fitted with Special Plow for Planting in Narrow Rows.

Has four cultivator teeth, landslide plow, pair of rakes, in addition to the side hoes.

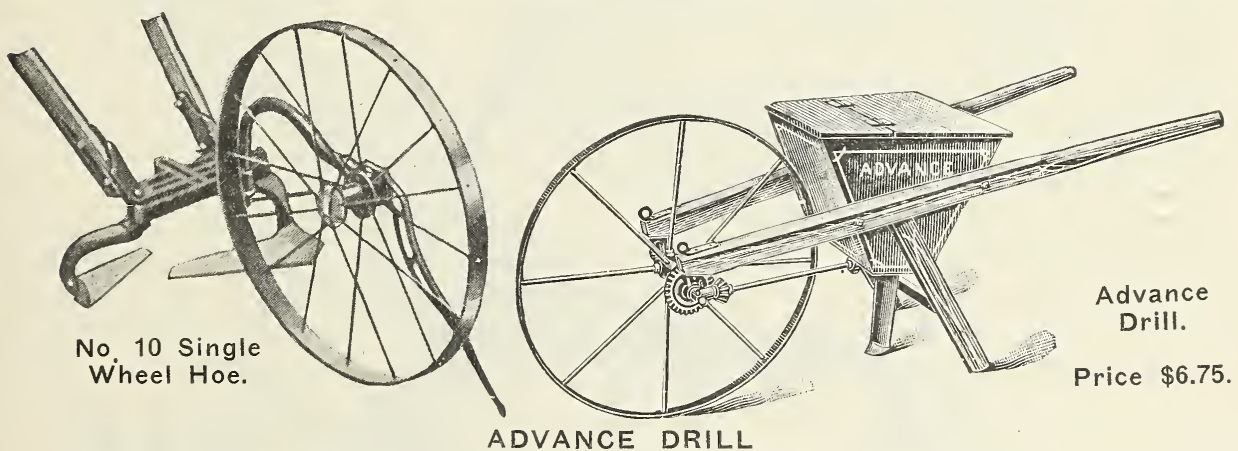

For fertilizer and for peas, beans and corn. Hopper holds 18 quarts. Sows accurately and has force feed. Can be used with a horse if necessary.

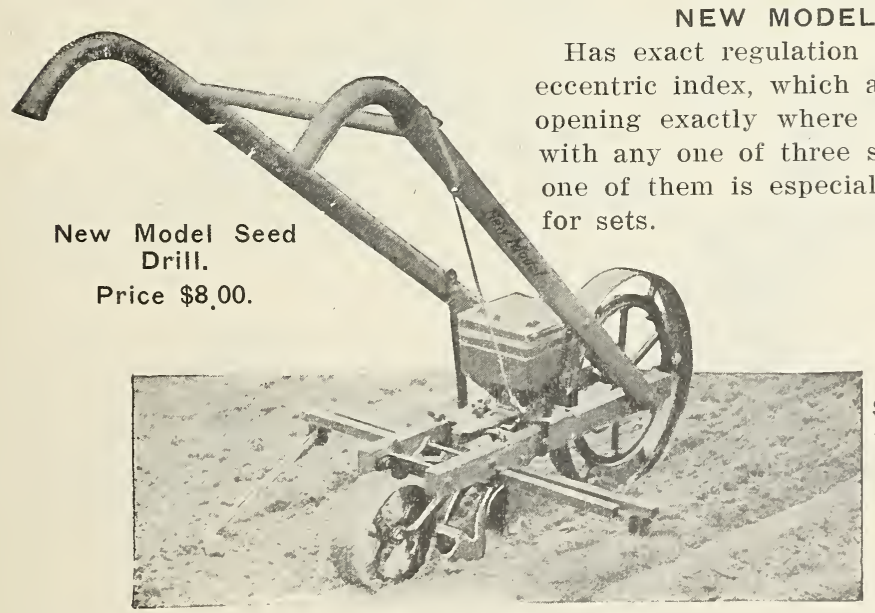

See complete descriptions in New Iron Age Garden Tool Booklet. 


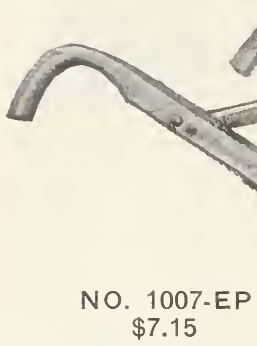

Strong points on these cultivators are the long, high steel frames; they run steady and clear of trash - the standards for the hoes and teeth are adjustable for any angle; the frame can be expanded for various width rows, with plain or lever expanders-they are furnished with or

\section{IRON AGE Horse Hoes, Harrows and Cultivators}

They are made in many styles and sizes for general and special uses. You need a new Iron Age booklet covering the whole line before you decide. We show but three here-there al' twenty or more from which to choose.

i ithout expander levers, plain or level wheels as cultivators or as horse hoes.

NO. 1007-EP is a seven-tooth cultivator for first workings or in level cultivation. Two-inch teeth are used which run deep without injury to young plants. Opens to 24 inches and closes to 10 .

NO 600-EP is a combined Horse Hoe and Cultivator which may be adjusted for all kinds of work. Range of cultivation 30 inches down to 14 .

NO. 1014-EP has 14 diamond shaped
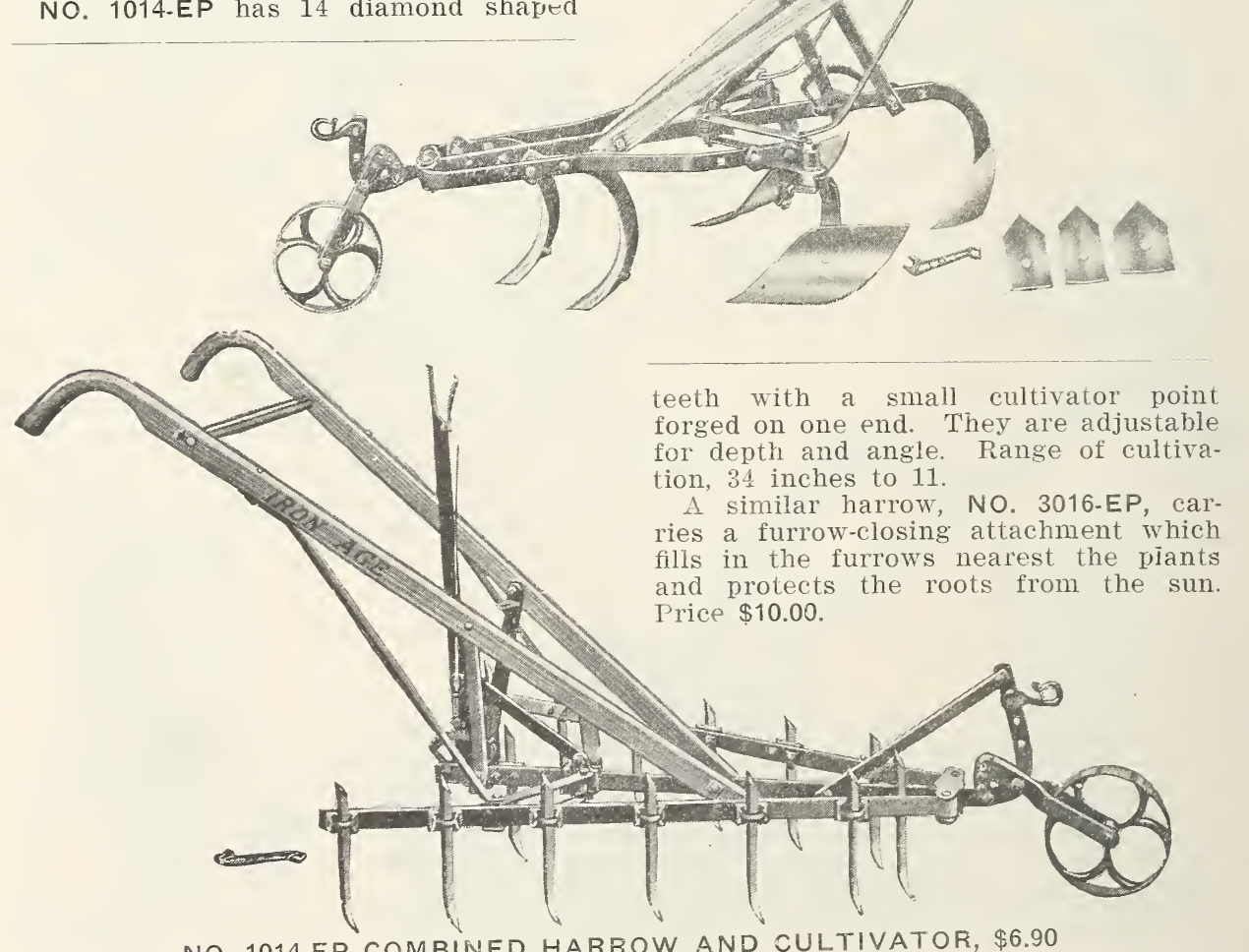

NO. 1014-EP COMBINED HARROW AND CULTIVATOR, $\$ 6,90$ 


\section{OLIVER PLOWS}

\section{GREAT IS THE NAME OF OLIVER !}

For over half a century the Oliver Plow has stood for all that intrinsic value in a plow represents. Every civilized country in the world has had its face furrowed with the iron edge of an Oliver Plow.

James Oliver, the founder of this vast business, has gone home to his reward, but behind him he has left in the minds and hearts of the people a monument more lasting than the pyramids of Egypt and a fame more secure than any garland chieftain ever dreamed of.

The new line of Steel Beam Plows recently put upon the market by the OLIVERS is the talk of the whole country. Of the many styles of plows turned out by this firm I have selected a few only, as my space is limited.

For further information please call and look my line over or write me for catalogue. I also keep constantly on hand a full line of Oliver Plow repairs.

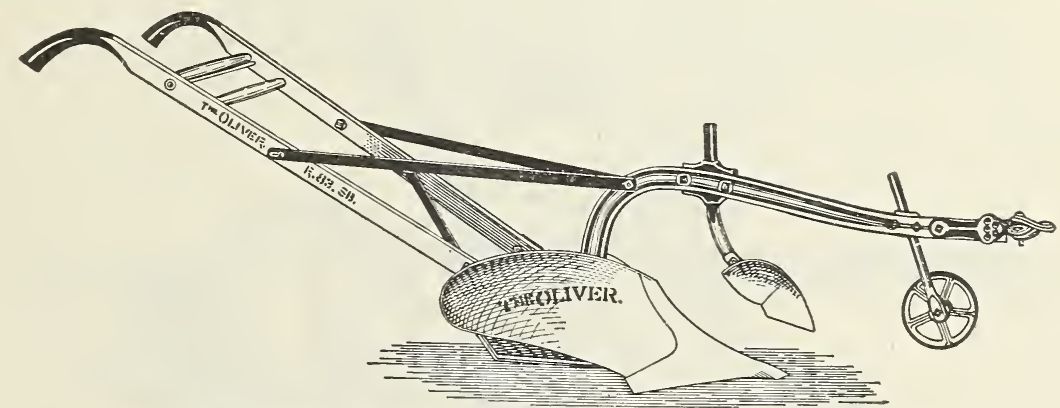

PRICE-No. 83, \$12.00; No. 84, \$13.00

The No. 83 Series, comprising Nos. 82, 83 and $8 \dot{4}$ Steel Beam Plows, are known as general purpose plows, and will give the best of satisfaction in almost any kind of soil. They are light in draft, with long moldboards, and every part strongly braced. The No. 82 is a light two-horse plow, the No. 83 a medium and the No. 84 a large two-horse or medium three-horse plow. They can be fitted with either chilled or steel moldboards.

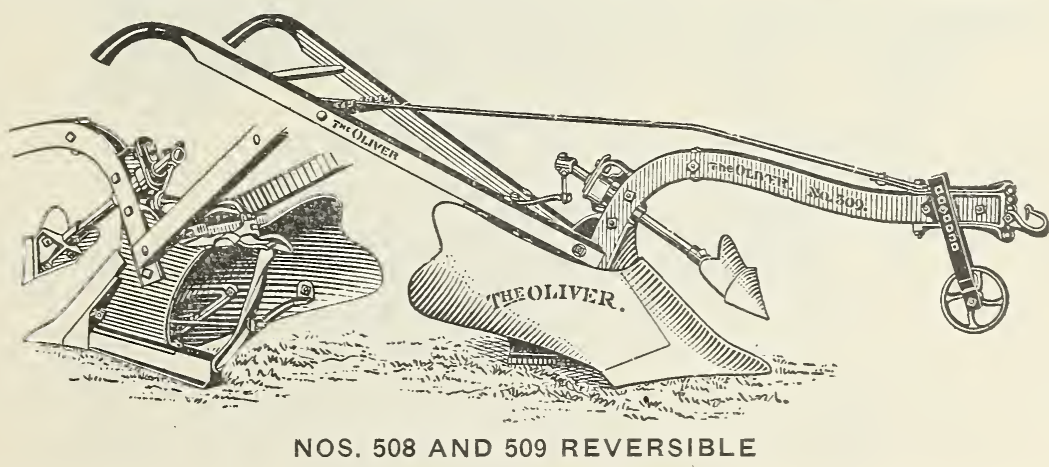

Work equally as well on flat land as sidehills. Capacity: No. 508, 5 to 8 in. deep by 10 to 13 in. wide; No. 509, 5 to 8 in. deep by 12 to 15 in. wide. Does away with dead furrows. Steel truss-beam made of forged steel, light and strong. Adjustable braced handles. Jointer or coulter works automatically with the moldboard, always in line with the cutting share. Has steel lever shifting clevis, changing the draft as desired. These plows can be fitted with either chilled or steel moldboards.

PRICE-No. 508, $\$ 14.00$; No. 509, $\$ 15.00$ 
"Let the Horses Do Your Work." 米

\section{THE OLIVER}

\section{No. 23 Reversible Sulky Plow}

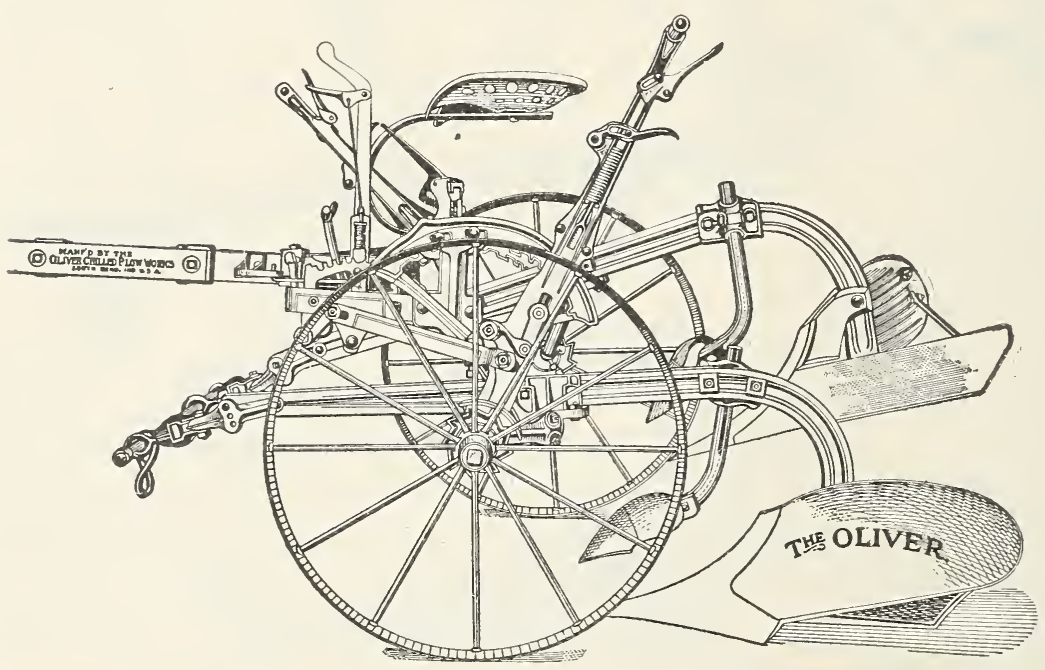

A NEW COMEINATION OF SPECIAL FEATURES

HORSE LIFT-Operate either by foot trip or hand latch. The operator's work diminished by one-half.

HINGED SEAT SPRING-So seat may be kept level on hillsides or in opening up a furrow. For this reason steeper hillsides can be plowed with greater safety, and the soft, yielding seat spring makes the operator much more comfortable.

Largest range of pole shift, and convenient guiding lever most effectively applied. Hitch never fails to operate correctly-a point where other sulkies fall down.

The No. 23 Sulky can be fitted with Nos. 82,83 or 84 chilled or steel bases.

\section{OLIVER CHILLED PLOW WORKS,}

SOUTH BEND, INDIANA, U. S. A. 


\section{OLIVER PLOWS}

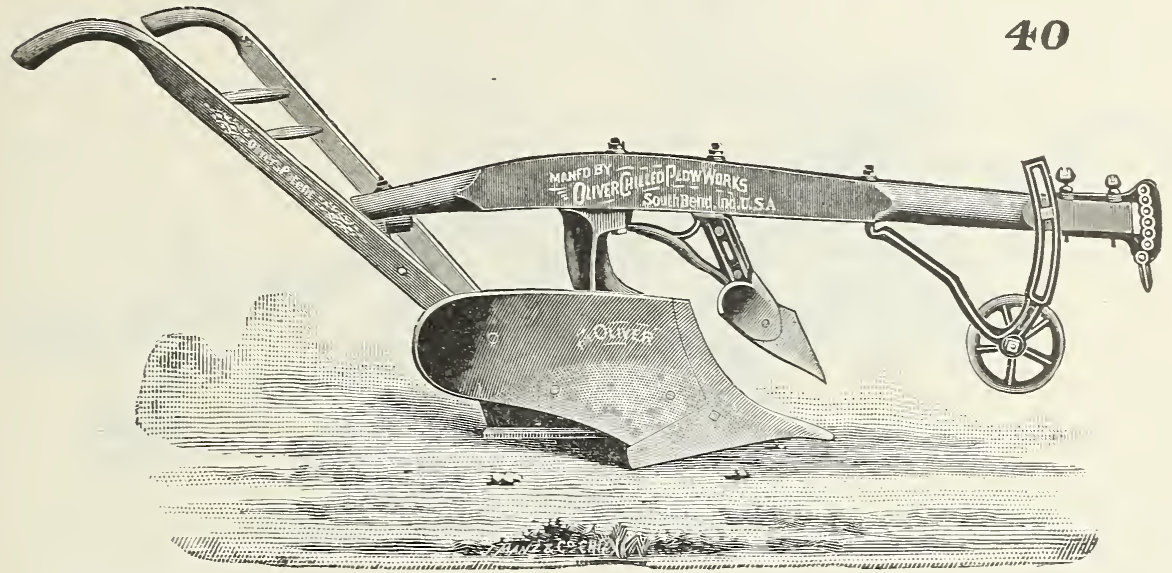

The OLIVER No. 40 has plowed clean, honest furrows around the world. They have been on the market 40 years and over a million of them have been sold in every civilized land under the sun. These are made right and left handed, in wood and steel beams. Price-No. 40 Oliver, Wood Beam, \$11.00; Steam Beam, \$12.50.

\section{Oliver No. 15 Pivot Axle Cultivator}

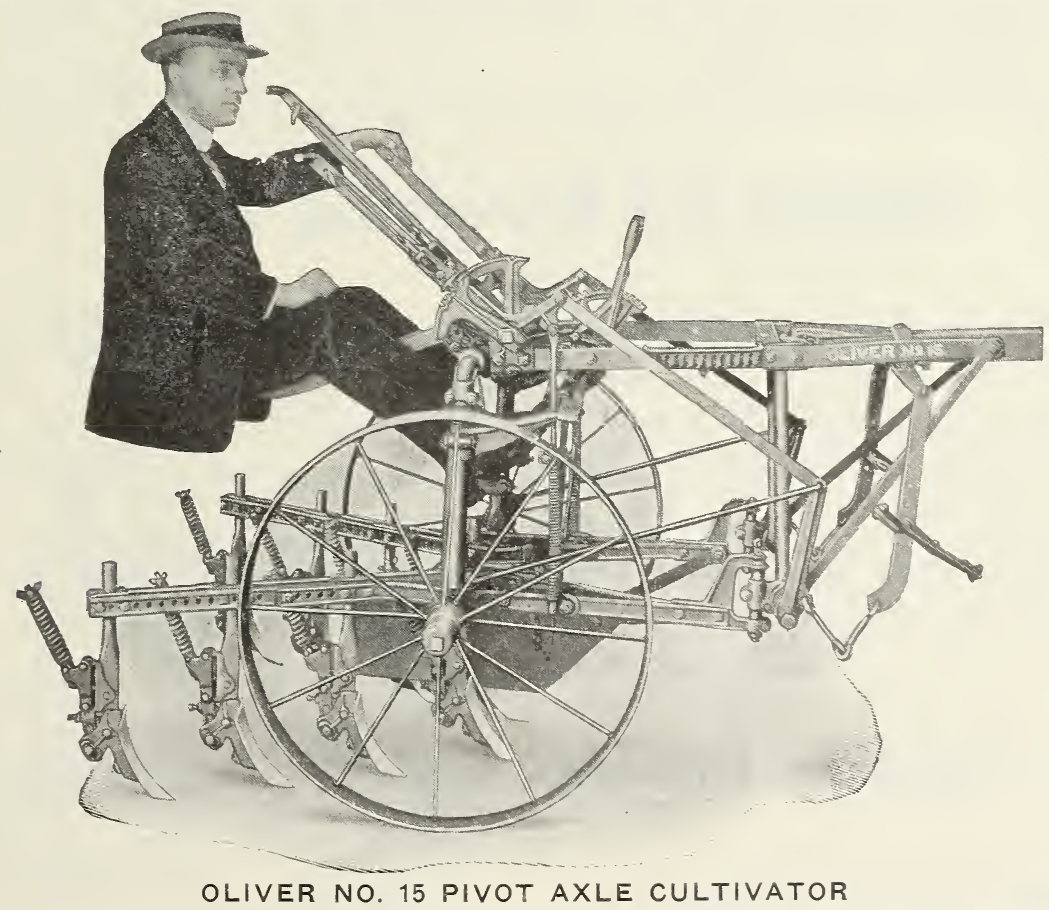

With the increased amount of truck farming of late years has come a demand for a cultivator that would work equally well in cultivating corn, beans, cabbage, tobacco and do general truck farming. This is a wide range of work for one machine. The No. 15 is well constructed of steel and malleable parts, and it has all the adjustments necessary to perform the required work. When you look at the machine you will agree with us that it will do the work well, and it is amply strong to stand up under reasonable use. 


\section{MUNNSVILLE PLOWS}

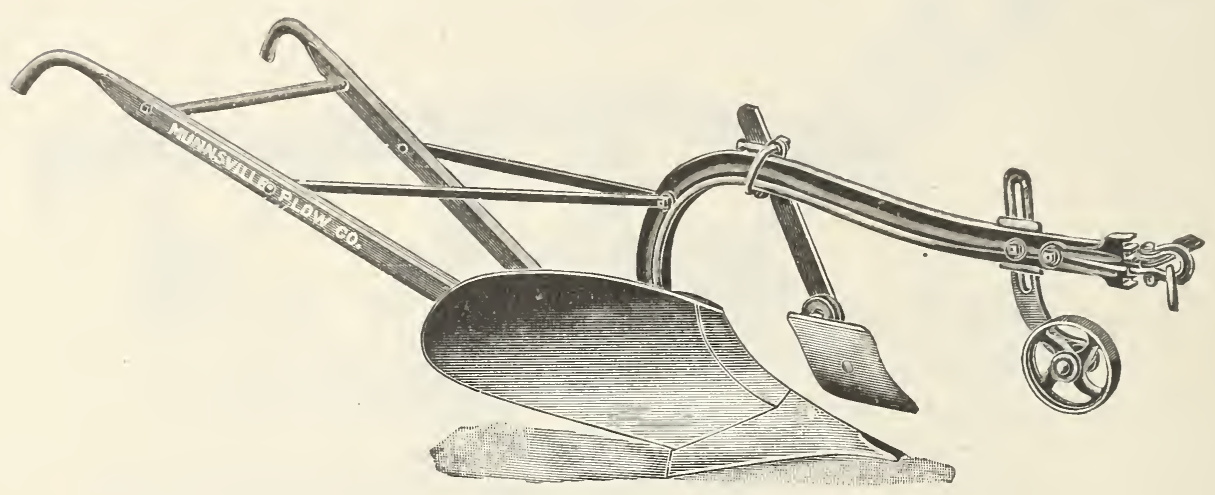

Some people think there is only one plow made and that is the Munnsville. Parties who have bought Munnsville Plows, as a rule, are willing to testify to their worth.

This firm turns out a number of different styles, of which I show one here, No. 56. Should you be interested, please call or write in for catalogue, prices, etc.

I can furnish a full line of repairs for Munnsville Plows.

No. 56 is a two-horse plow with a steel moldboard. It will turn a furrow 5 to 8 inches deep and 10 to 15 inches wide. It is one of the most popular plows turned out by this company. Price $\$ 13.00$.

\section{Haying and Harvesting Tools}

Don't forget that I am headquarters for Haying Tools of all kinds, besides other necessary things wanted at that time of the year. I shall carry in stock the Hay Carrier Barn Door Equipments mentioned in this catalogue, and Litter Carriers, also Scythes, Snaths, Pitch Forks, Barley Forks, Rakes, Rope of all kinds, Binder Twine, Iron and Wood Pulleys of all kinds, Machine Oil, Fly Oil, Kerosene and Separator Oils. Please give my goods a trial when you are ready for anything in this line.

\section{Pedigree Ensilage and Field Corns}

\section{Have you tried our Corn?}

This Corn is guaranteed true to name and of the highest vitality.

Considering results obtained, it is by far the cheapest Corn you can possibly buy. 


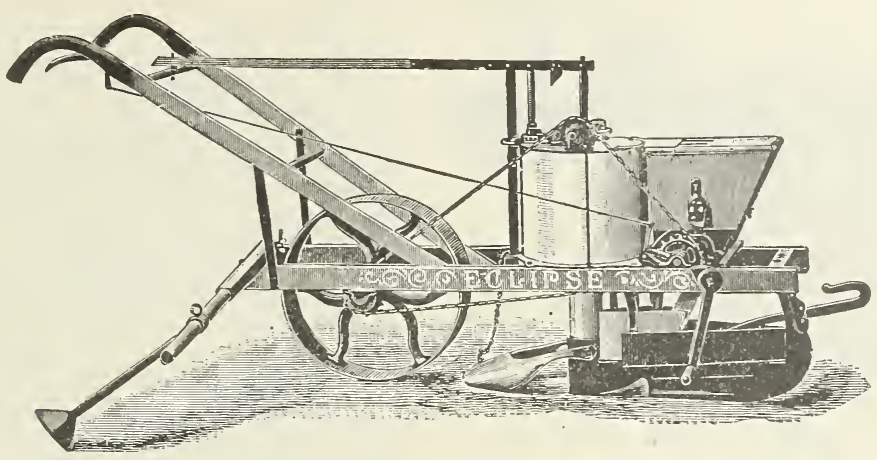

\section{ECLIPSE CORN PLANTER}

1. The Eclipse Planter is the only planter that will accurately distribute all commercial fertilizers wet as well as dry, in given amounts per acre in hill, drill or check.

2. The Eclipse is the only planter with a simple and practical marker attachment.

3. The Eclipse is the only planter having concave places each side of plow. This places the moist earth on the seed just before the fertilizer each side of it. This is a great advantage when the grain is dry, or during a dry season.

4. The Eclipse Planter is easily adjusted to drop seed and fertilizers in hills, drills or checks by the use of two sprocket wheels on seed roll shaft.

5. Six changes can be made for the amount of fertilizer used, varying from 50 to 450 pounds per acre, by simply inserting pins and turning a thumb nut on the cover without removing contents of hopper.

6. The seed dropper and valves are operated by the planter, and are simply controlled by a touch of the finger as it passes over the row.

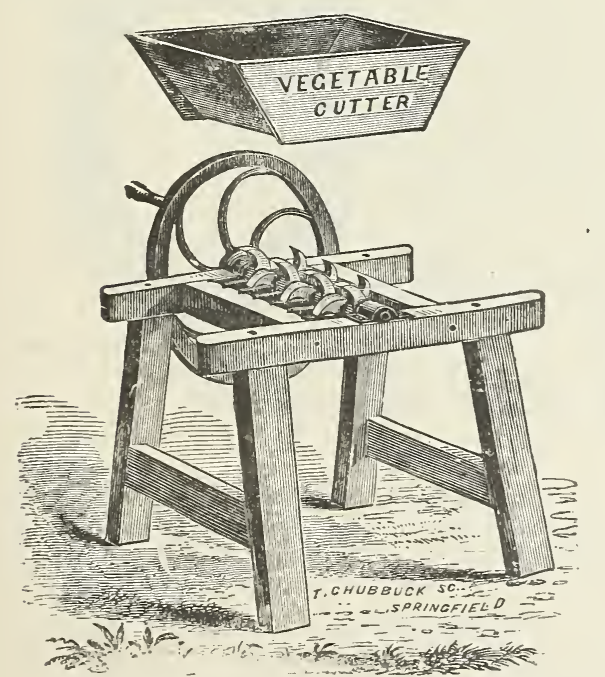

\section{CHAMPION ROOT CUTTERS}

Price $\$ 8.00$

Every farmer should own one
1. The Champion has a strong wooden frame and a heavy balance wheel.

2. The teeth are curved hooks revolving on a shaft and pass between knives attached to the bottom of the hopper.

3. The Champion will cut up all kinds of vegetables, such as beets, turnips, carrots, cabbages, mangles, pumpkins, etc.

If interested in above goods please write for descriptive circulars and price on same 


\section{HARVESTER HAY CARRIER AND TRACK}

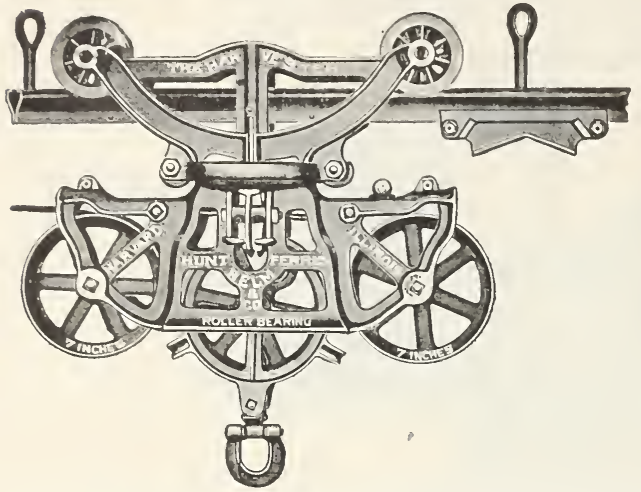

This is the most romplete and easy running equipment of its kind. The carrier illustrated is the reversible fork carrier. It will work either way from the trip block rumning to either end of the track without changing the rope.

The lock is simple, safe and sure-a gravity lock with no springs. The locking parts are $11 / 4$ " thick.

'The carrier has a wide open mouth so that the fork pulley can enter it at any angle. It is impossible to miss connections.

The sheaves of this carrier are $7^{\prime \prime}$ in diameter, are roller bearing and are grooved for $7 / 8$ " rope or $3 / 8$ " wire cable.

The carrier illustrated runs on Star est track made. '1 nis track is also the easiest to hang.

Double Flange Steel Track-the strong-

The hangers are removable and fit the track at the point wherever the rafter comes.

The trip block is also removable and can be fastened to the track at any desired point.

Harvester carriers are also made to run on wood track or cable track and are made in many other designs than the one above illustrated.

Please write for descriptive circular, or, better still, call at my store and see for rourself.

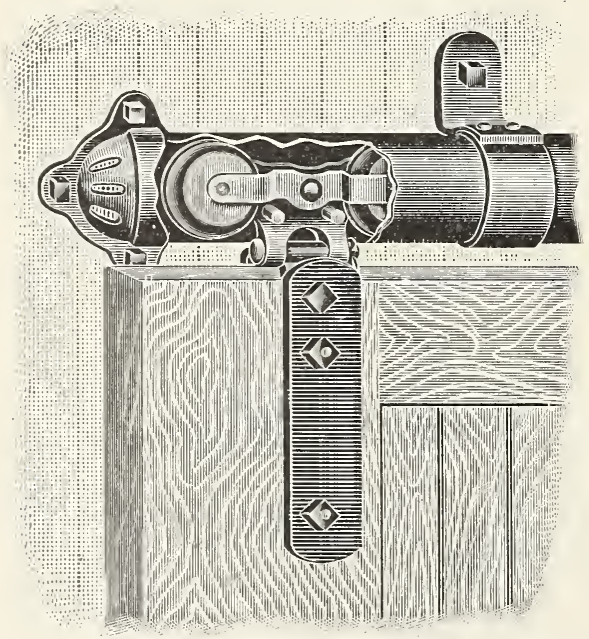

Cannon Ball Barn Door Hangers.

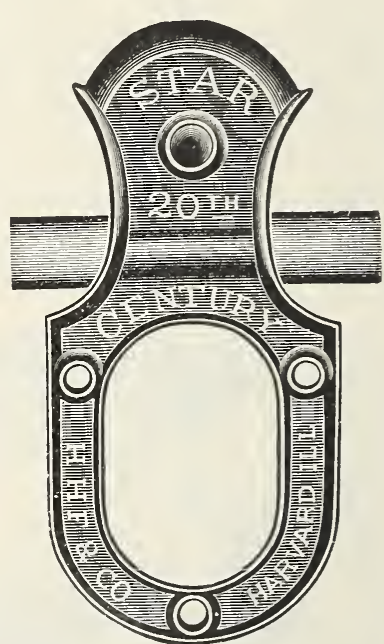

20th Century B. D. Hangers.

\section{CANNON BALL BARN DOOR HANGERS}

This is the best hanger ever sold for barn doors:

1. Because it is all enclosed and strictly waterproof. The track is tubular and made of No. 14 gauge steel and it is made in three-foot sections, $21 / 4$ " in diameter, the sections being joined together in steel splices. It is slotted $1 / 4$ " on the under side to take hanger frame.

2. The hanger wheels are made of hollow steel balls and are noiseless and roller bearing in their action.

3. The pendant can be adjusted to work either laterally or vertically or both with the use of an ordinary wrench.

For further particulars regarding the Cannon Ball Barn Door Hanger, please write for circular, or, better still, call at my store and investigate for yourself. 


\section{FULL ROLLER-BEARING STAR LITTER CARRIER Large Rcller-Bearing Tracker Wheels, Roller-Bearing Shaft.}

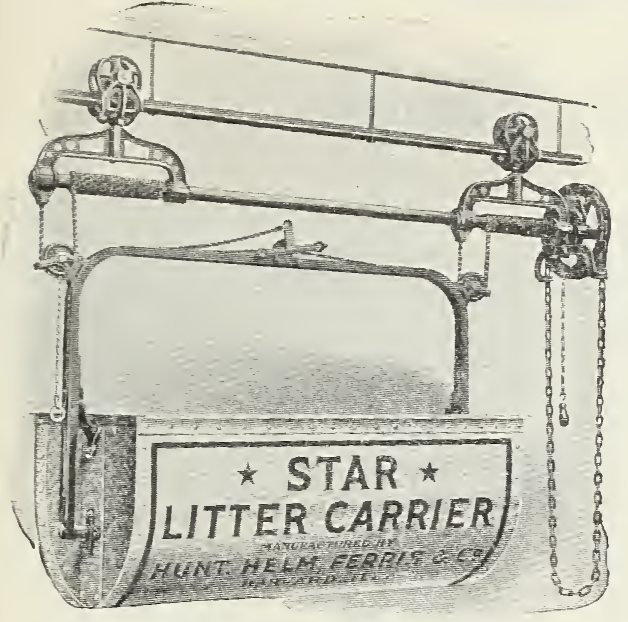

Without a doubt this carrier is the most reliable made. It is in use by thousands of farmers. They say it is O. K. Isn't that enough? Constructed of heavy, malleable iron; load held from four different points on the steel shaft. Note that we use winding chains, instead of cable, which unravels. Four sizes of all-steel tubs that dump either way, so you don't have to pack it heavy on one side to make it dump, as in others. Some farmers may think it necessary to use a rod or cable carrier to have one that will return automatically. A mistaken idea, because with the siai Carrier for rigid steel track, here illustrated, we furnish an Automatic Dumping and Returning Device, by rue ise of which you can run your carrier to dump and return it same as a rod or cable carrier.

Pulling 56 lbs. on the hand chain raises 320 lbs. in tub. Carrier is fitted with a quick lifting device; you don't want a slow one. This is the only carrier made that dumps either way. Remember this! We also manufacture the Star Feed Carrier, using the same carrier with raising and lowering device as shown in Fig. 333, fitted, however, with a large double end feed tub-the sides being constructed of wood, the bottom of heavy galvanized iron. The tub will hold ten bushels.

We also manufacture Star Milk Can Carrier, using in its construction the same carrier as shown in Fig. 333, only it is fitted to carry either one, two or three milk cans. The Star Milk Can Carrier is a distinct improvement over the old style platform carriers insomuch as the cans may be filled on the floor or held suspended. A can may be lowered to an inch of the floor, and therefore it is unnecessary to bring them in contact with the barn floor, thus insuring a perfect sanitary conditicn.

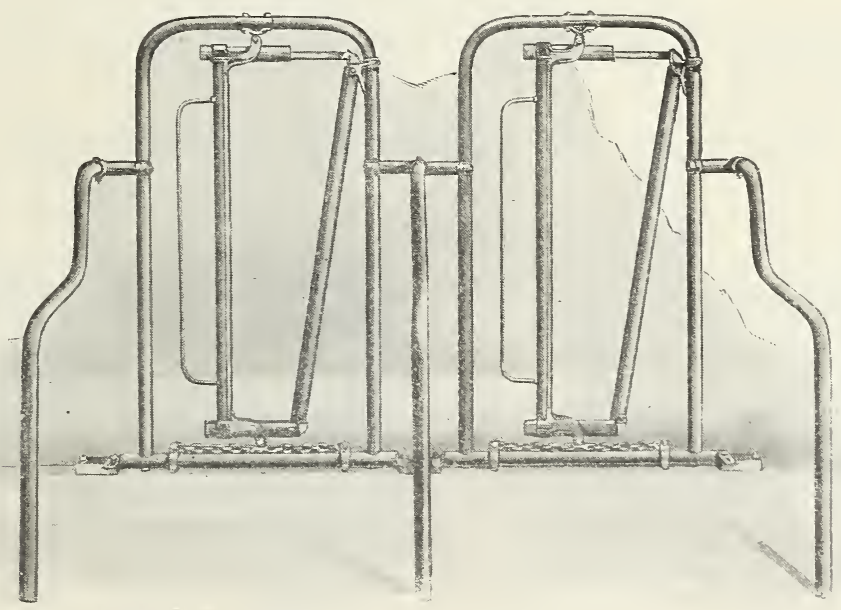

\section{STAR SANITARY BARN EQUIPMENT \\ The Urit System Stall.}

This equipment is endorsed by Farmers, State Boards, and Milk Inspectors everywhere. It means a wonderful saving in time and labor. It will pay for itself the first year. It includes many features and improvements over the older styles of sanitary equipment. The stall arch is of one smooth rounded piece of bent steel tubingno clamp irons or other dust and germ catchers. It is easy to clean and to keep clean.

Stalls quickly adjusted for long or short cows, and stanchions instantly adjustable to neck width. This equipment is practically assembled before shipment. Is easy to set in place. Stanchions fitted with patented lock and guide. Easily opened with one hand. Closed by slamming them shut. On account of the guide can't miss locking. Guide also prevents any strain coming on the hinge-the weak point with stanchions of other makes. Double hanging at the bottom is adjustable. 


\section{SAND TRAY}

\section{Prairie State Incubator}

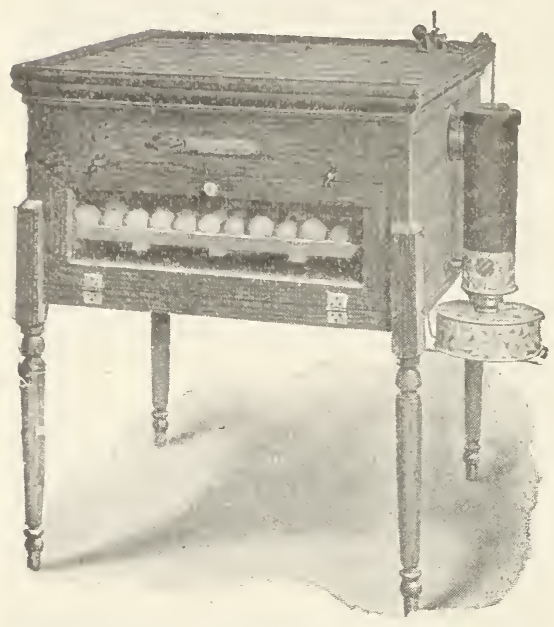

No. 1, CAPACITY 150 EGGS, PRICE, \$22.50.

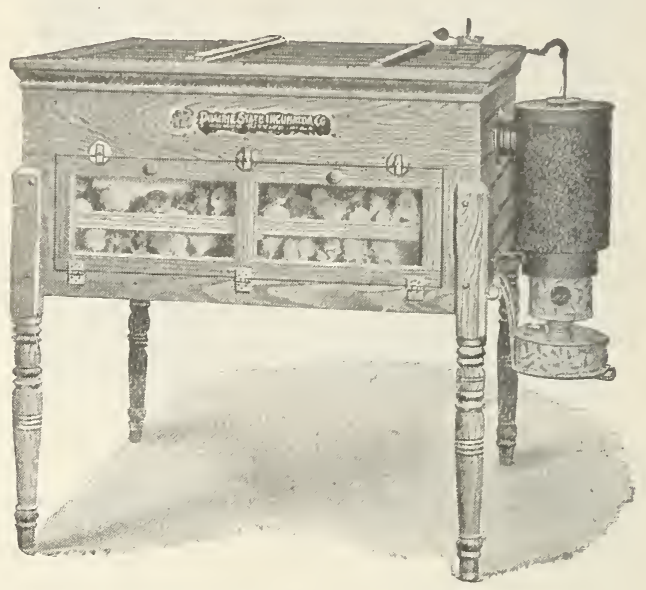

No. 2, CAPACITY 240 EGGS, PRICE, \$32.00.

NO. 3, CAPACITY 390 EGGS, $\$ 38.00$

This firm makes a cheaper machine, called the Keystone. No. 0, 60 Egg, $\$ 9.00$; No. 1, 100, Egg, $\$ 12.00$.

\section{PRAIRIE STATE SAND TRAY INCUBATORS}

The ONLY true principle of ARTIFICIAL INCUBATION. GUARANTEED to produce more livable chicks than any incubator ever manufactured.

It embodies every principle or device that can produce chicks of the strongest vitality. These incubators are absolutely fireproof. The heat is applied to the upper part of the egg chamber by means of a metal radiator, and this principle of radiant heat, in combination with diffusive heat and the resultant humidity of air in the machine, approaches more nearly to the natural conditions than any system of artificial incubation known to science. It contains many features, among which are the following:

First-The Eddy Current or Automatic Gravity Heat Distributor.

Second-A new Toggle Joint, Thermostatic and Automatic Heat Regulator.

Third-Automatic Regulation and Uniform Moisture Supply from the Sand Trays. Fourth-Supplementary Ventilation for drying chicks before removal to brooders.

Fifth-Large Air Space above and below the eggs.

Sixth-Removable Burlap Mats in bottom of nursery.

Seventh-A Warm Nursery that can be used in the coldest of rooms.

Eighth-Egg Trays contain any size eggs.

Ninth-The combination of elements that produces the largest and strongest chicks that have ever been hatched artificially.

Tenth-A durable, well made machine that will last.

If Interested, Write Me for Complete Incubator Catalogue. Free on Request. 


\section{Prairie State Brooders and Hovers}
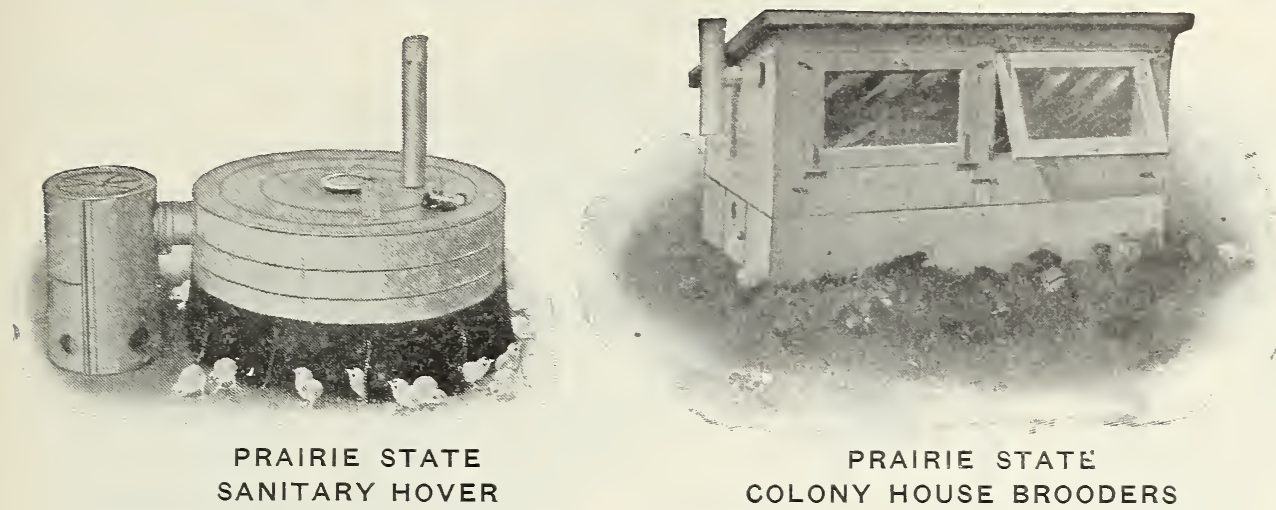

This is what the manufacturers say of them: "We guarantee them to raise chicks out of doors, or by any means whatsoever.'"

These Brooders and Hovers have the following points of superiority:

1. They are unusually large and roomy.

2. The floor is on one level, no inclines.

3. The chicks never get lost or chilled.

4. The thermometer can be read from the front without disturbing any of the doors.

5. The chicks can be cared for and brooder perfectly ventilated without disturbing the roof.

Prairie State Sanitary Hovers can be attached to any form of outdoor brooder or any kind of colony house, shed coop, piano or organ box. They can be relied on at all times for perfect service.

Price, complete with regulator.................. $\$ 8.50$

If interested, write for Special Brooder and Hover Catalogue.

\section{Cyphers' Incubators, Brooders and Hovers}
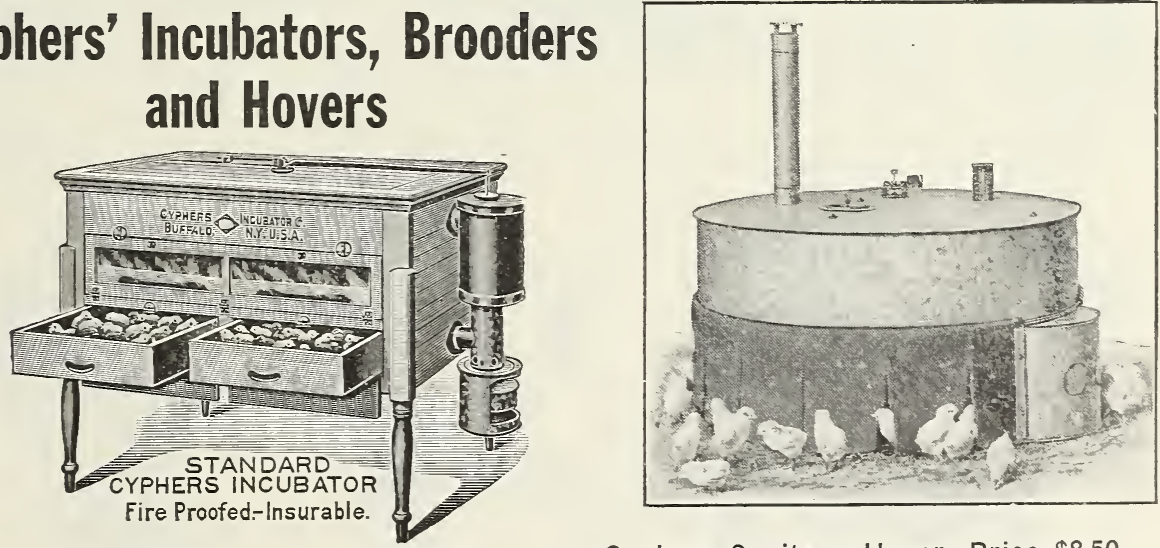

Cyphers Sanitary Hover, Price $\$ 8.50$

These goods needs no introduction at my hands. Many people believe that there is no machine made equal to a Cyphers. We have them here for your inspection and will be pleased to furnish you all the information possible regarding them. Complete catalogue furnished on application.

This Incubator is made in four sizes:

No. 0 Capacity $70 \ldots \ldots \ldots \ldots \ldots 15.00$

No. 1 Capacity $144 \ldots \ldots \ldots \ldots \ldots \ldots 22.00$

No. 2 Capacity $244 \ldots \ldots \ldots \ldots \ldots . . \ldots 32.00$

No. 3 Capacity $390 \ldots \ldots \ldots \ldots \ldots . . \ldots 38.00$
The Outdoor Brooder in three sizes: Style A................. \$13.50

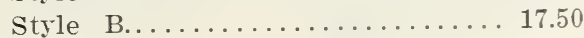
Style C......................... 190 Also other styles for less price. 


\section{"Mandy Lee" Incubators and Brooders}

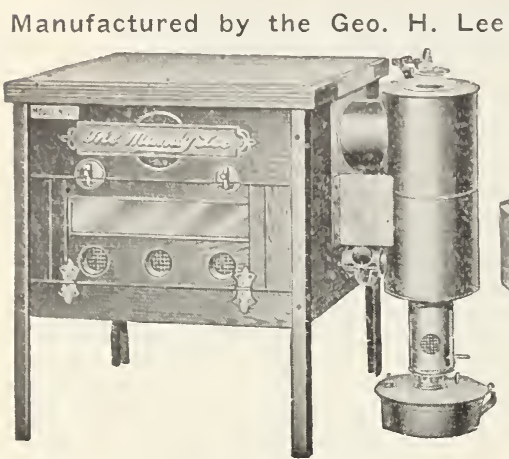

In order to meet the demand for a good Incubator of smaller capacity that could be sold for less money I have placed in stock the following:

Mandy Lee, Jr., 60-egg capacity. Price....\$10.00 Mandy Lee, 75-egg ca-

pacity. Price..... 13.00 Can furnish larger sizes of the Mandy Lee if necessary. I also carry in stock the Mandy Lee 60-Chick Brooder. Price $\$ 6.00$.

Regular Mandy Lee Indoor Brooder. Price $\$ 13.00$.

Complete catalogue Lee's Goods furnished application.

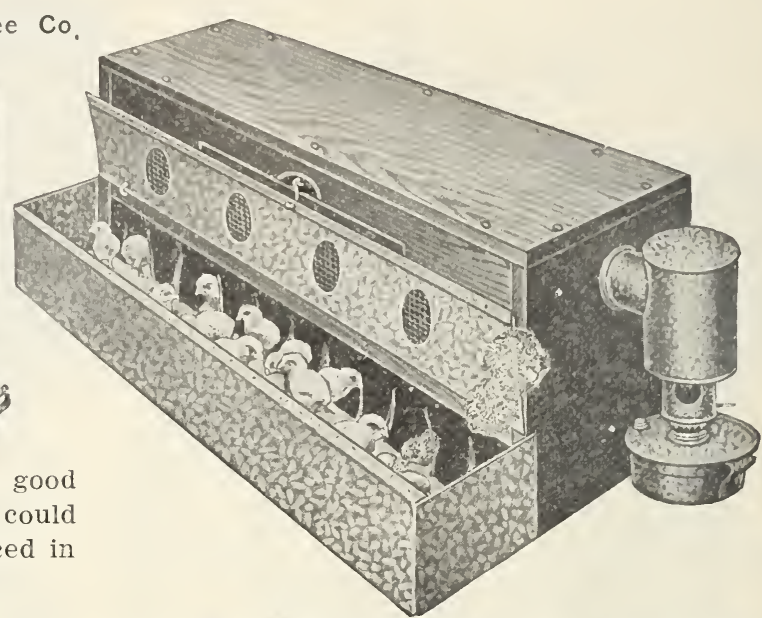

Lee's Liquid

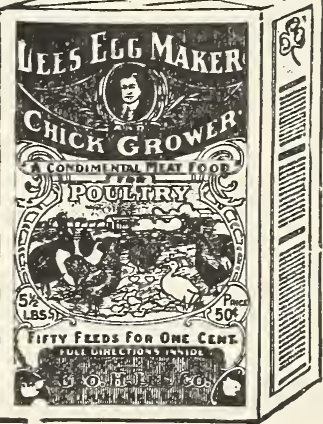
Lice Killer; Lee’s Egg Producer; Lee's Germozone;

Three Articles of Highest Merit.

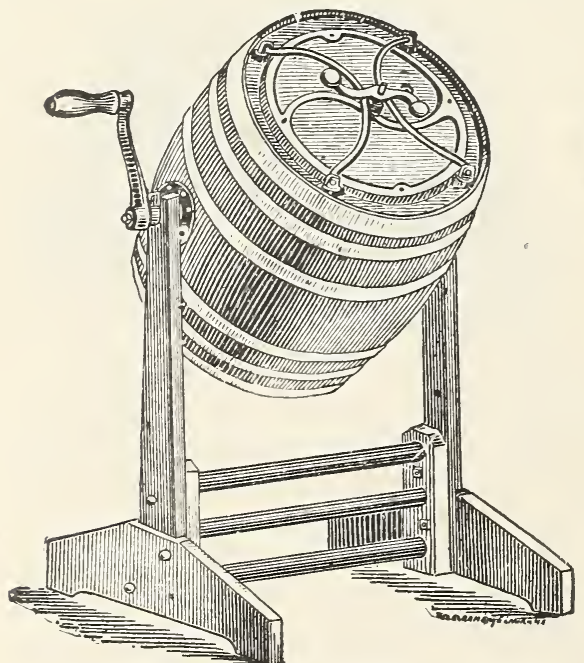

THE JACKSON BARREL CHURN. All sizes. Price, $\$ 4.00$ up.

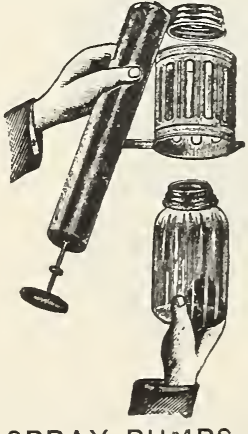

SPRAY PUMPS

All kinds, all sizes, all prices.

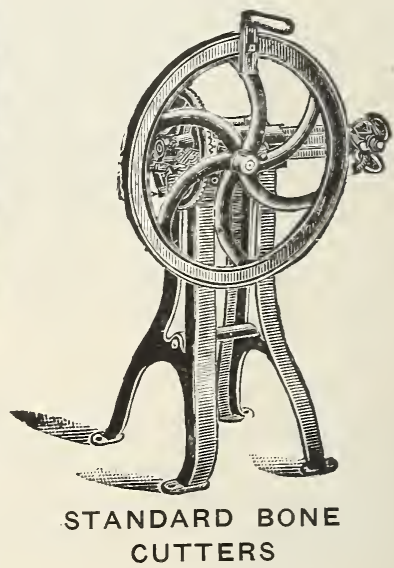

All sizes, $\$ 8.75$ up.

Guaranteed to do better work than any bone cutter on the market. 


\section{There is Only One "BEST"}

\section{Satisfaction or Your Money Back. Pratts.

\section{PRATT'S POULTRY REGULATOR}

The best and most famous

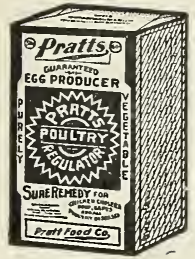
poultry tonic in the world. Keeps fowls of all kinds healthy, increases egg-production, aids moulting. Makes little chicks grow rapidly. In packages, $25 \mathrm{c}$, $50 \mathrm{c}, \quad \$ 1.00 . \quad 12-1 \mathrm{~b} . \quad$ pails, $\$ 1.25$. $100-1 \mathrm{l}$. bag, $\$ 9.00$.

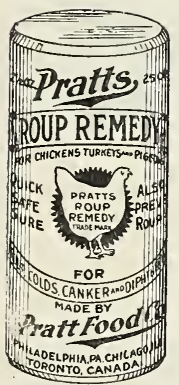

\section{PRATT'S ROUP REMEDY}

Pills or Powder

is a scientific preparation guaranteed to prevent and cure roup, colds, canker, catarrh and diphtheria. In severe cases individual treatment with the Pills is the only sure method. For mild cases, and as a preventive, crush the pills or use the powdered form, and $\operatorname{mix}$ in the drinking water. Sold in $25 \mathrm{c}, 50 \mathrm{c}$ and $\$ 1.00$ boxes.

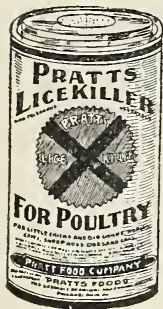

\section{PRATT'S POWDERED}

\section{LICE-KILLER}

A powerful insecticide and disinfectant in powdered form; put up in sprinkler top boxes. The increased eggproduction due to the ridding your fowls of vermin will surprise you. It pays well to use it. $25 \mathrm{c}$ and $50 \mathrm{c}$

\section{PRATT'S BABY CHICK FOOD}

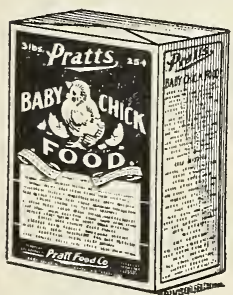

This is one of the greatest Money Savers and greatest Chick Savers ever placed on the market. Every man, woman or child who raises little chicks, turkeys, ducks and geese should try at least one package of Pratt's Baby Chick Food. It is a scientific food ration to be fed for the first three weeks. If you want REAL SUCCESS with your hatches, if you want to save all the baby chicks, if you want them to grow fast, get Pratt's Baby Chick Food on our recommendation for your first trial, after that you will never be without it. Put up in 1 lb., $3 \mathrm{lb}, 6_{1 / 2} \mathrm{lb}$. packages, also 14 lb., 25 1b., $50 \mathrm{lb}$. and 100 lb. bags.

A "bracer" for overworked, run-down poultry. Keeps show birds in the pink of condition; puts flesh on thin birds; prevents colds, roup and liver troubles. We guarantee this Remedy to satisfy you or refund purchase price. $25 \mathrm{c}$ and $50 \mathrm{c}$ a box.
Bronchitis in poultry is fatal in a few days unless promptly checked with Pratt's Bronchitis Remedy. This remedy is sure, safe and quick and will save your birds. $25 \mathrm{c}$ and $50 \mathrm{c}$ boxes. Mailed postpaid on receipt of price.

\section{PRATT'S ANIMAL REGULATOR}

America's pioneer and best animal tonic and regu lator; enables your horse to do more work; saves feed, increases your cows' milk, puts your hogs, sheep and steers in fattening condition, makes and keeps all stock healthy. 25-1b. pail, \$3. In packages and sacks

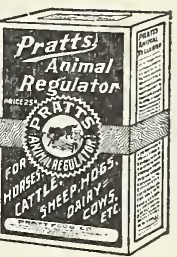
from 25c upward. It pays to use large sizes.

PRATT'S VETERINARY COLIC CURE

A guaranteed colic cure with a record of 998 cures out of 1,000 cases. You should always have a bottle handy. Its use is "horse insurance." In $50 \mathrm{c}$ and $\$ 1.00$ bottles.

\section{PRATT'S LINIMENT}

A guaranteed liniment for use in cases of lameness, sprains, bruises, rheưmatism, sore throat, etc., in either man or beast. A real wonder worker. $25 \mathrm{c}, 50 \mathrm{c}$ and $\$ 1.00$ bottles.

\section{PRATT'S HEALING OINTMENT}

For man or beast.

A splendid antiseptic healing ointment for cuts, galls, scratches, etc. Allays inflammation and heals quickly without a scab. In $25 \mathrm{c}$ and $50 \mathrm{c}$ boxes.

\section{PRATT'S CHOLERA REMEDY}

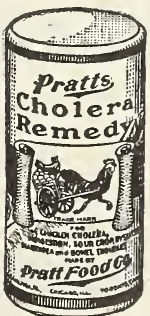
is an unfailing remedy for this disease and is a "guaranteed or money back" article which is prepared under our own supervision in our own laboratories. It is administered in the drinking water, and will be found of great value, not only for treating cholera but also in cases of indigestion, sour crop, dysentery, diarrhœa and bowel trouble. 25c and 50 .

\section{PRATT'S CONDITION TABLETS}




\section{Drs. Hess \& Clark’s Specialties.}

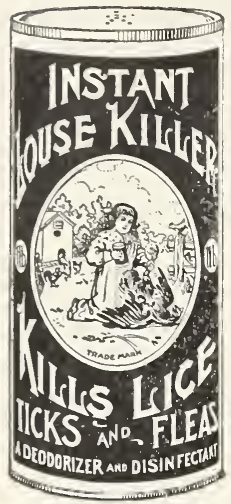

\section{Instant Louse Killer.}

Kills lice on stock and poultry, mites, sheep ticks, fleas on dogs, bugs on cucumber, squash and melon vines, slugs on rose bushes.

\section{Poultry Panacea.}

A guaranteed scientific poultry tonic which makes the young grow fast, healthy and strong, cures Indigestion, Leg Weakness, Diarrhœa.

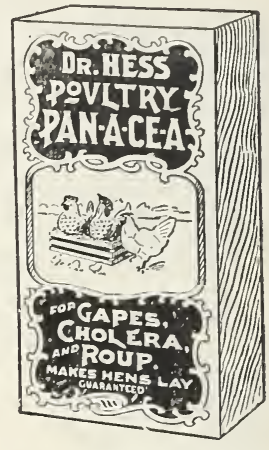

\section{Dr. Hess' Stock Food}

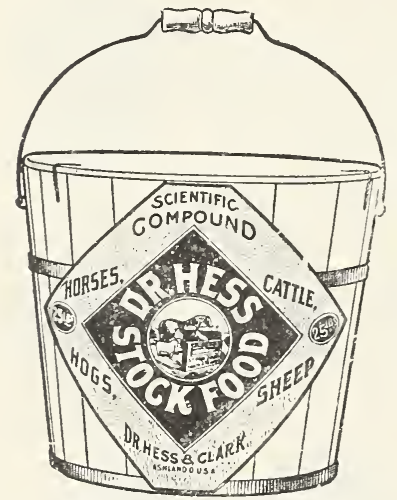

fills the milk pails. Weigh or measure your milk for ten days, then for ten days continue the same rations and feed Dr. Hess' Stock Food as directed. If you do not have a notable increase both in quality and quantity of milk return the empty package and your money will be refunded.

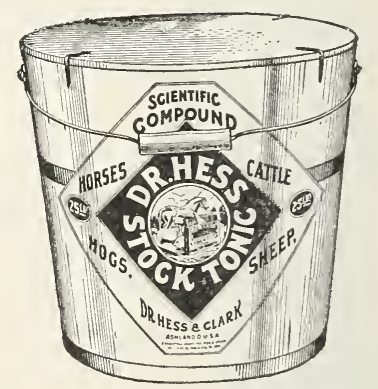

Dr. Hess' Healing Powder

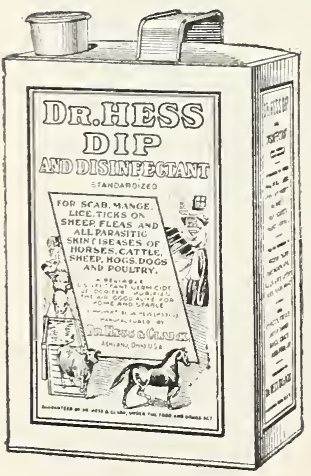

will cure harness sores and open wounds of every description.

\section{Dr. Hess' Worm Powder}

expels worms from stock and poultry.

\section{Dr. Hess' Heave Powder}

cures heaves if the lung cells are not broken down.

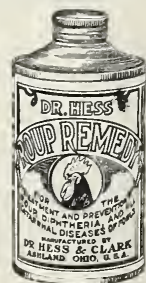




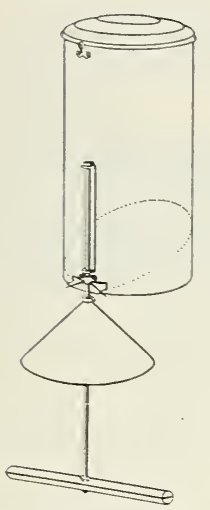

\section{GILLETTE \\ EXERCISE FEEDER}

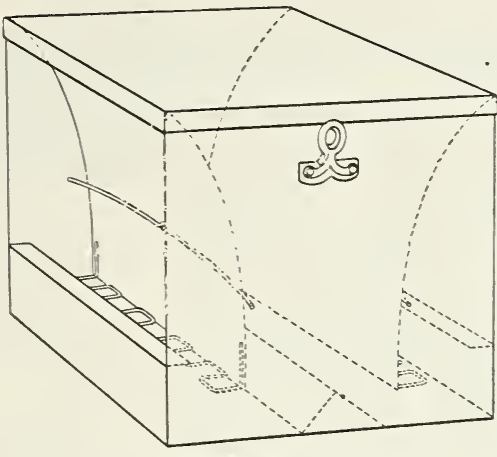

GILLETTE GRAIN AND GRIT HOPPER
THE STANDARD

A WELL VENTILATED

GALVANIZED

CHICKEN COOP

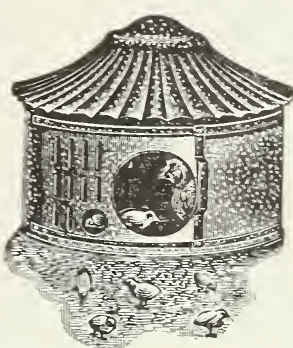

Is Rain, Rat and Termin Proof and an absolutely safe and sanitary home.

PRICE $\$ 2.50$

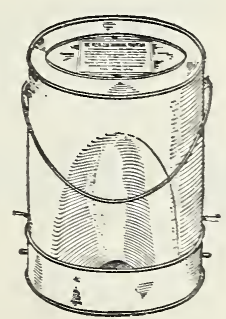

\section{THE PEERLESS DRINKING FOUNTAIN}

is right. The water is always pure. It is protected from dirt and filth. Easy to clean and fill and fowl cannot injure their combs when drinking. Simple in construction, durable and practical. It is adjustable. If it becomes too loose or too tight, spring the sides of the fountain in or out as it may require, until the bottom rim is a perfect fit. Made in two sizes, 5-quart for 25 fowls and 10-quart for 40 to 50 fowls.

\section{5-Quart Peerless Fountains, 60c.}

\section{THE PEERLESS HEATER}

The water will never freeze or become too warm. Easy to care for. Costs but little to run. Every 5-qt. Peerless Fountain fits the Heater.

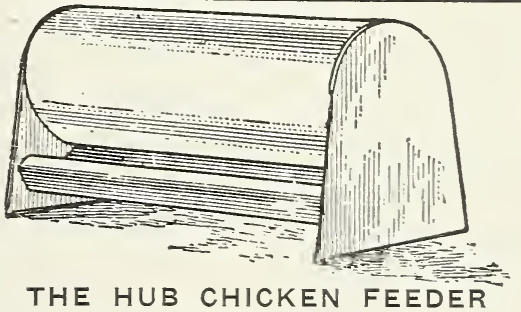

is sanitary, keeps the feed clean and dry. Chickens cannot get into it, and cannot waste the feed. It will pay to use the Hub Feeder for small chickens. Chicken feed costs money. The Hub Feeder saves chicken feed. At night turn the feeder over backwards until face down and nothing can get into it.

9-in. Feeder, 35c. 15-in. Feeder, 50c.

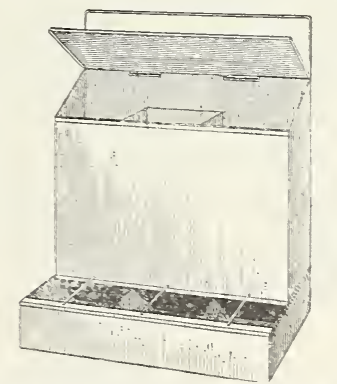

1-2-3 POULTRY FEEDER

for Dry Mash, Scraps, Grit, Charcoal or any poultry feed. When used for one kind of feed only take out separator; for two kinds put separator in one end; when used for three kinds, say scraps, shells and grit, put separator in the middle and you have three separate feeders.

1-2-3 Poultry Feeder, $75 \mathrm{c}$ 


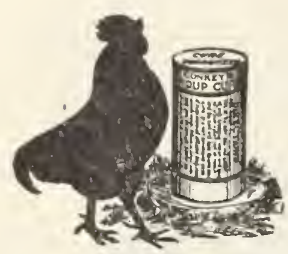

CONKEY'S ROUP

\section{AILING FOWLS ARE A DEAD LOSS}

WE HAVE

\section{Conkey's Poultry Remedies}

A Special, Guaranteed Remedy for Each Distinct Disease. watery discharge from nose and eyes. Conkey's Roup Cure cures them. Given in drinking water once a week, it will prevent this disease. Prices, 50c, $\$ 1.00$. Trial package, 25c, postpaid.

CONKEY'S CHOLERA REMEDY-For diarrhœa, dysentery, sour crop-all diseases of the digestive organs. Guaranteed. Price, $50 \mathrm{c}, 60 \mathrm{c}$, postpaid.

CONKEY'S LICE POWDER-In a class by itself. Absolutely kills body lice instantly and doesn't hurt bird or taint eggs in nest. Save your flock from these terrible pests. Guaranteed. $10 \mathrm{c}$ size, $15 \mathrm{c}$ postpaid; $25 \mathrm{c}$ size, $40 \mathrm{c}$ postpaid. Also in $50 \mathrm{c}$ and $\$ 1.00$ sizes.

Send for Complete List of Conkey Remedies. All Sold on Money Back Guarantee.' One for Each Distinct Disease.

\section{List of Poultry Supplies and Apparatus}

My stock is large and complete, embracing everything that a poultryman may need in Feeds, Apparatus and Supplies in general. I take pleasure in calling your attention to the following goods, which I constantly keep on hand at all times:

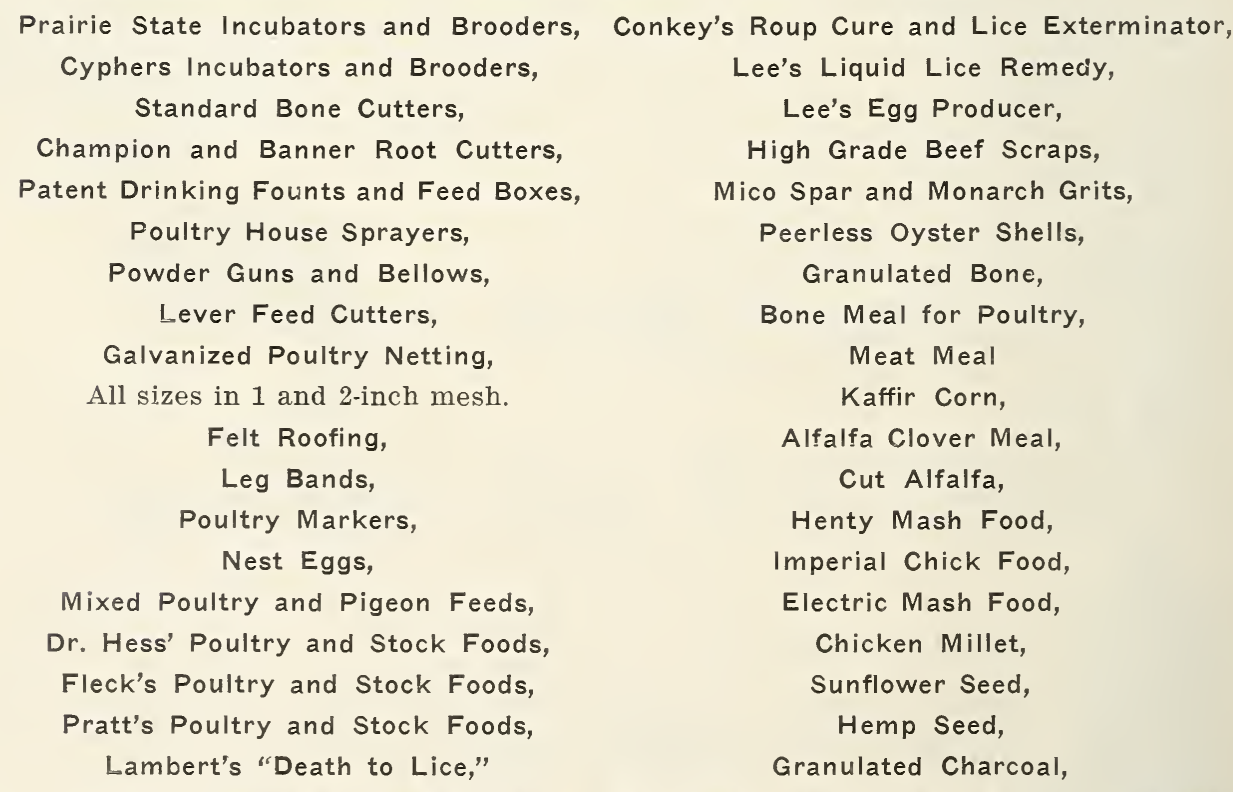
Conkey's Cholera and Gape Cure,

Remedies for all kinds of Poultry Diseases. 


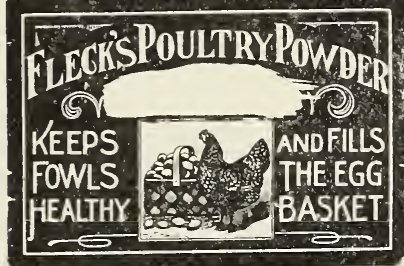

FLECK'S

POULTRY POWDER, LICE EXTERMINATOR, STOCK FOODS.

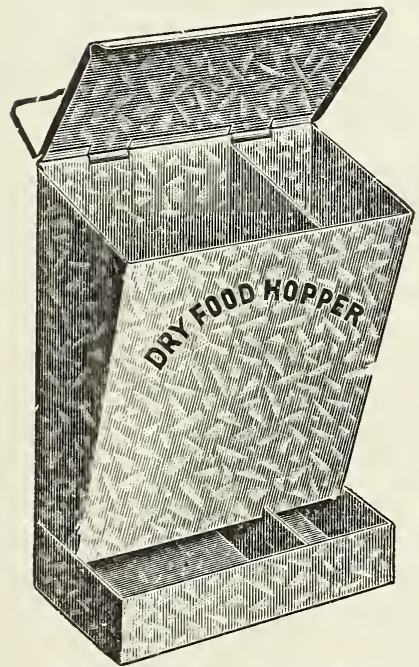

Galv. Iron Dry Food Box. Price $75 c$.

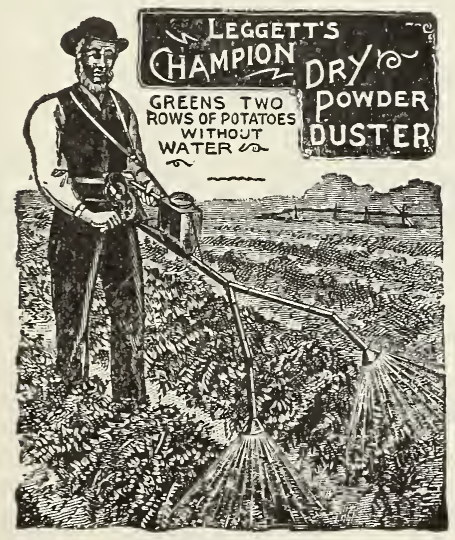

Leggett's Champion Dry Powder Duster.
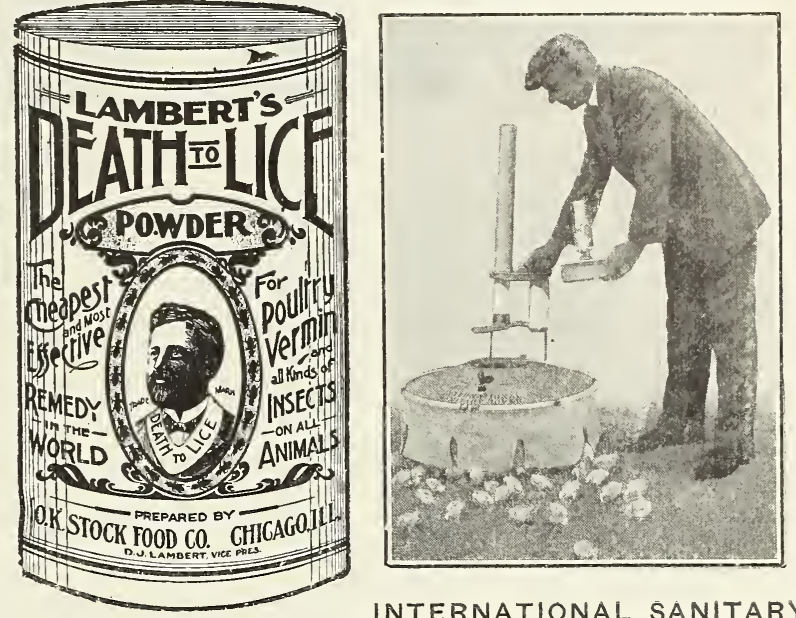

INTERNATIONAL SANITARY HOVER
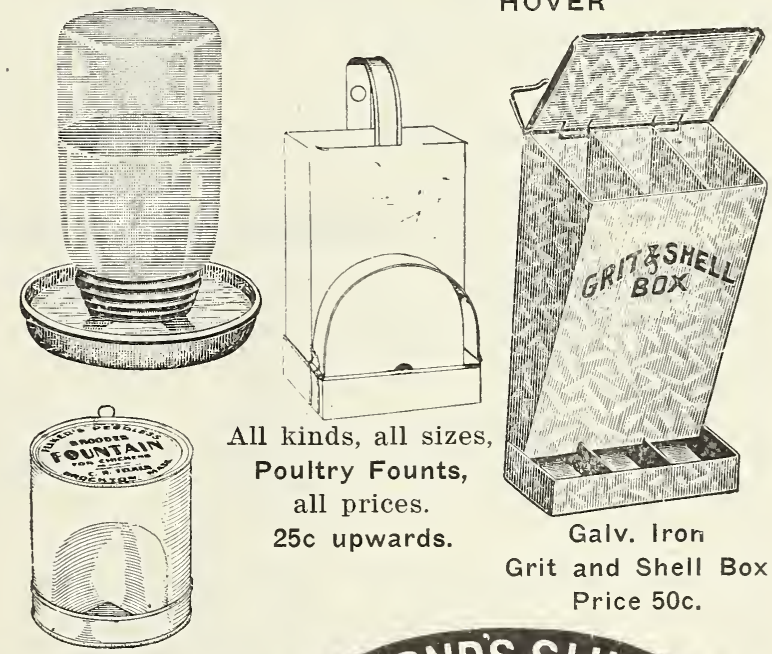

25c upwards.

Grit and Shell Box Price 50c.

\section{Felker's}

Founts, all sizes.
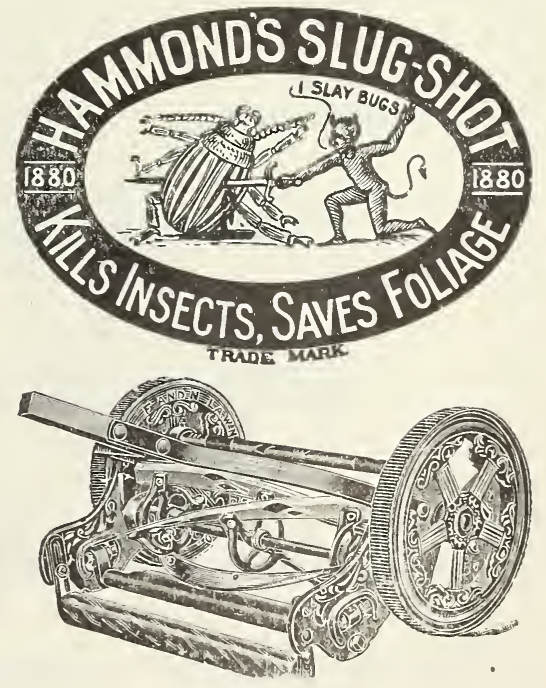

Lawn Mowers,

All sizes, all prices. 


\section{Milkmen's Supplies}

This is another line I talie pride in calling your attention to. Everything that is of use to a milk dealer or to a tarmer in the line of Farm Dairy Supplies or Apparatus can be found in this department. Moreover, the goods 1 offer you under this head are of the VERY BEST quality and as low in price as any first-class stock can be offered at anywhere. My list includes the following articles:

$\begin{array}{lll}\text { FACTORY CANS, } & \text { BUTTER JARS, } & \text { BOTTLE BRUSHES, } \\ \text { PEDDLING CANS, } & \text { MILK DIPPERS, } & \text { CAN SCRUBS, } \\ \text { PEDDLING PAILS, } & \text { BUTTER PAPER, } & \text { RUBBER MOPS, } \\ \text { MILK PAILS, } & \text { SEPARATOR OIL, } & \text { MILKING TUBES, } \\ \text { COVERED MILK BUCKETS, } & \text { MILK BOTTLES, } & \text { STRAINER CLOTH, } \\ \text { MILK STRAINERS, } & \text { BOTTLE CARRIERS, } & \text { BUTTER COLOR, } \\ \text { MEASURING RODS, } & \text { BOTTLE CRATES, } & \text { TEST TUBES, } \\ \text { DAIRY THERMOMETERS, } & \text { BOTTLE CAPS, } & \text { MILK PANS. }\end{array}$

WYANDOTTE-The Great Cleaner and Cleanser. Used by over 90 per cent of the Creameries and Cheese Factories.

\section{MISCELLANEOUS}

$\begin{array}{lll}\text { BARBED WIRE, } & \text { CROSS CUT SAWS, } & \text { LAWN MOWERS, } \\ \text { BARBED WIRE STAPLES, } & \text { HAND SAWS, } & \text { HINGES, } \\ \text { BINDER TWINE, } & \text { AXES, } & \text { NAILS, } \\ \text { ROPE, AII Sizes, } & \text { PICKS, } & \text { SCREWS, } \\ \text { HALTERS, } & \text { CROWBARS, } & \text { BOLTS, } \\ \text { CURRY COMBS, } & \text { MAULS, } & \text { HAMMERS, } \\ \text { LANTERNS, } & \text { SCYTHES, } & \text { HATCHETS, } \\ \text { KEROSENE OIL, } & \text { SNATHS, } & \text { WRENCHES, } \\ \text { MACHINE OIL, } & \text { PITCH FORKS, } & \text { SCREW DRIVERS, } \\ \text { FLY OIL, } & \text { MANURE FORKS, } & \text { MEAT JARS, } \\ \text { SPRAY PUMPS, } & \text { BARLEY FORKS, } & \text { BUTTER JARS, } \\ \text { SPRINKLERS, } & \text { TIN MEASURES, } & \text { PRUNING KNIVES, } \\ \text { RAKES, } & \text { WOODEN MEASURES, } & \text { HEDGE SHEARS, } \\ \text { SHOVELS, } & \text { BUSHEL BASKETS, } & \text { PARING KNIVES, } \\ \text { HOES, } & \text { MARKET BASKETS, } & \text { CUTLERY, } \\ \text { BUCK SAWS, } & \text { VEGETABLE CRATES, } & \text { PADLOCKS. }\end{array}$

The largest and most complete establishment in Central New vork devoted especially to the interests of the farming community. When you need anything in the lines indicated I trust you will give me a call. I am especially well qualified to care for you in everything pertaining to the seed business.

\section{MILTON T. JONES}

Batchelor Block UTICA, N. Y. 14 Liberty Street 


\section{SONES'}

\section{Imperial Lawn Grass Seeds}

The Court House Lawn is Made from this Seed.

I can also furnish the Genuine Lawn Grass Seed and Permanent

Pasture and Meadow Mixtures, having bought out the business of the Batchelor Seed Store of this city

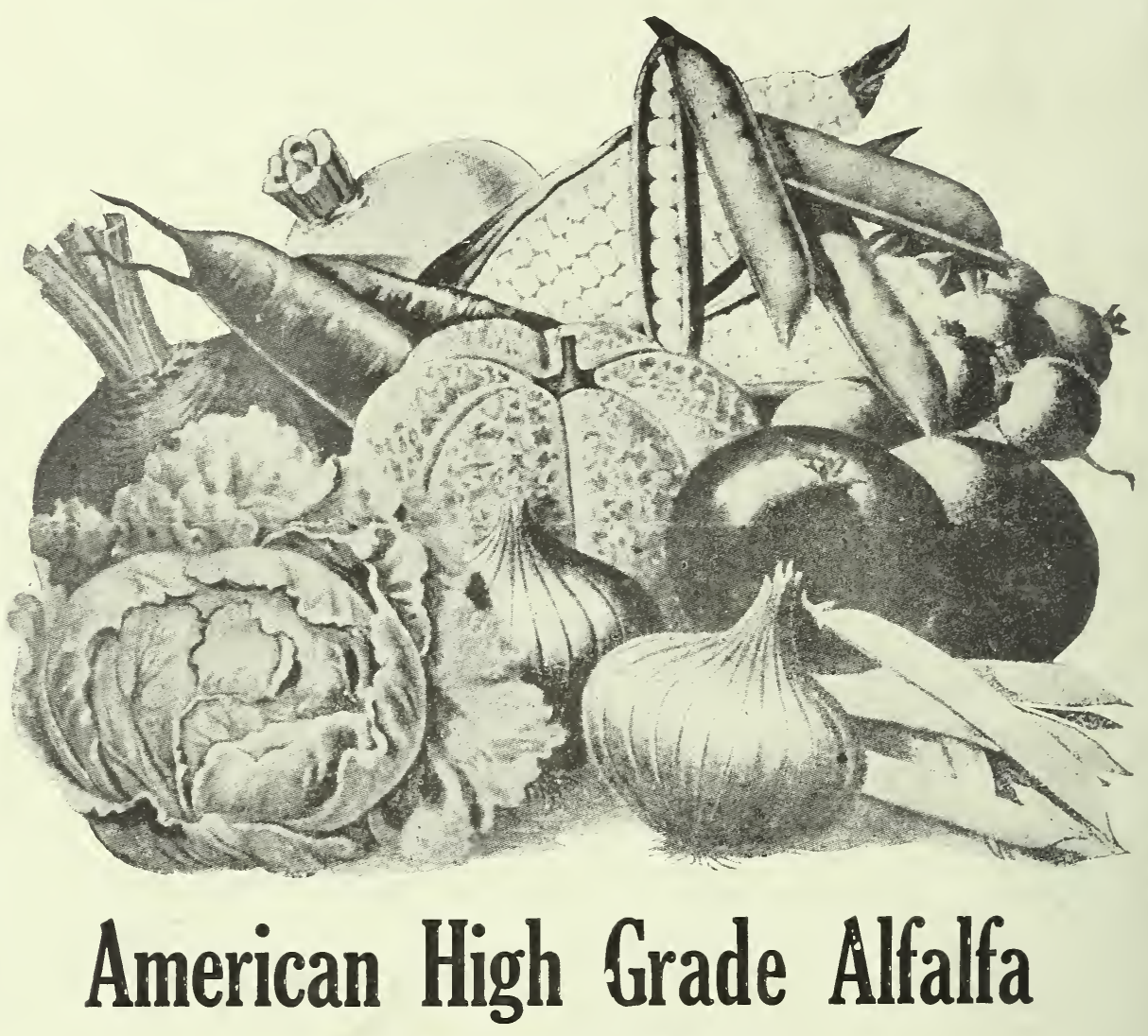

Free from trefoil and dodder. CHOICE RED, WHITE AND ALSYKE CLOVERS.

State Timothy and Choice Western Timothy.

Pedigree Ensilage and Field Corn.

True to name and of highest vitality.

Considering results, the cheapest corn you can possibly buy. 